\title{
Sectoral Impacts of Invasive Species in the United States and Approaches to Management
}

\author{
Anne S. Marsh, Deborah C. Hayes, Patrice N. Klein, \\ Nicole Zimmerman, Alison Dalsimer, Douglas A. Burkett, \\ Cynthia D. Huebner, Robert Rabaglia, Laura A. Meyerson, \\ Bonnie L. Harper-Lore, Jamie L. Davidson, Marla R. Emery, \\ Travis Warziniack, Rebecca Flitcroft, Becky K. Kerns, \\ and Vanessa M. Lopez
}

\subsection{Introduction}

Invasive species have a major effect on many sectors of the U.S. economy and on the well-being of its citizens. Their presence impacts animal and human health, military readiness, urban vegetation and infrastructure, water, energy and transportations systems, and indigenous peoples in the United States (Table 9.1). They alter bio-physical systems and cultural practices and require significant public and private expenditure for control. This chapter provides examples of the impacts to human systems and explains mechanisms of invasive species' establishment and spread within sectors of

\section{A. S. Marsh ( $\varangle) \cdot$ D. C. Hayes}

U.S. Department of Agriculture, Forest Service, Sustainable Forest Management Research, Washington, DC, USA

e-mail: anne.marsh@usda.gov

P. N. Klein

U.S. Department of Agriculture, Forest Service, Research and Development, Landscape and Ecosystem Services Research, Washington, DC, USA

N. Zimmerman

Ecological Society of America, Washington, DC, USA

A. Dalsimer

U.S. Department of Defense, Mark Center, Alexandria, VA, USA

D. A. Burkett

U.S. Department of Defense, Armed Forces Pest Management Board, Silver Spring, MD, USA

C. D. Huebner

U.S. Department of Agriculture, Forest Service, Northern Research Station, Morgantown, WV, USA

R. Rabaglia

U.S. Department of Agriculture, Forest Service, State \& Private

Forestry, Forest Health Protection, Washington Office,

Washington, DC, USA the U.S. economy. The chapter is not intended to be comprehensive but rather to provide insight into the range and severity of impacts. Examples provide context for ongoing Federal programs and initiatives; support State and private efforts to prevent the introduction and spread of invasive species; and to eradicate and control established invasive species.

Invasive species are a problem for humans as well as the ecosystems they inhabit as economic impact analyses have indicated (Pimentel 2011; Pimentel et al. 2005). Approximately 50,000 non-native species have been introduced into the United States, including plants, animals, and microbes (Pimentel et al. 2005). Many of these species were intentionally introduced to control erosion or as agricultural

L. A. Meyerson

University of Rhode Island, Kingston, RI, USA

B. L. Harper-Lore

U.S. Department of Transportation, Federal Highway

Administration, Washington, DC, USA

J. L. Davidson

U.S. Department of Agriculture, Forest Service, Allegheny

National Forest, Warren, PA, USA

M. R. Emery

U.S. Department of Agriculture, Forest Service, Northern Research Station, Burlington, VT, USA

T. Warziniack

U.S. Department of Agriculture, Forest Service, Rocky Mountain Research Station, Fort Collins, CO, USA

R. Flitcroft · B. K. Kerns

U.S. Department of Agriculture, Forest Service, Pacific Northwest Research Station, Corvallis, OR, USA

V. M. Lopez

U.S. Department of Agriculture, Forest Service, State \& Private Forestry, Forest Health Protection, Washington Office, Washington, DC, USA 
Table 9.1 Key impacts of invasive species on the humans and the systems that support them ${ }^{\mathrm{a}}$

\begin{tabular}{l|l}
\hline Sector & Impact \\
\hline $\begin{array}{l}\text { Animal and } \\
\text { human health }\end{array}$ & $\begin{array}{l}\text { Spread of infectious disease; dermatitis; } \\
\text { respiratory allergies; wounds and bites; loss of } \\
\text { native species }\end{array}$ \\
\hline $\begin{array}{l}\text { Military } \\
\text { readiness }\end{array}$ & $\begin{array}{l}\text { Diminished military force health; decreased } \\
\text { aircraft safety; decreased safety on training } \\
\text { grounds; hampered movement of equipment, } \\
\text { vehicles, and supplies; equipment and } \\
\text { infrastructure damage }\end{array}$ \\
\hline Urban areas & $\begin{array}{l}\text { Tree damage and mortality; infrastructure } \\
\text { damage; loss of native species }\end{array}$ \\
\hline $\begin{array}{l}\text { Water resources } \\
\text { and systems }\end{array}$ & $\begin{array}{l}\text { Decreased water quality and quantity; flooding; } \\
\text { water infrastructure damage; diminished } \\
\text { recreational opportunities }\end{array}$ \\
\hline Energy systems & $\begin{array}{l}\text { Damage to electrical equipment, utility lines, } \\
\text { and poles; damage to hydropower facilities }\end{array}$ \\
\hline $\begin{array}{l}\text { Transportation } \\
\text { systems }\end{array}$ & $\begin{array}{l}\text { Reduced visibility; flooding; increased fire risk; } \\
\text { damage to roadways and railroad tracks and ties }\end{array}$ \\
\hline $\begin{array}{l}\text { Forest and } \\
\text { grassland } \\
\text { products }\end{array}$ & $\begin{array}{l}\text { Decreased forage; cattle poisoning; disease } \\
\text { transmission to cattle; loss of timber and } \\
\text { non-timber forest products }\end{array}$ \\
\hline $\begin{array}{l}\text { Indigenous } \\
\text { peoples }\end{array}$ & $\begin{array}{l}\text { Loss of native foods, medicines, ceremonial } \\
\text { materials, and species with cultural value }\end{array}$ \\
\hline
\end{tabular}

${ }^{a}$ With proper control and management measures, many impacts can be avoided or abated

crops, livestock, landscaping, game species, or pets. Others were accidental hitchhikers on imported products or came by natural catastrophic disturbances, such as hurricanes. Once established in the United States, many of these species became invasive ( 6500 species) and have caused significant unintended economic losses, threatened human and animal health and safety, and disrupted human activities. Some of the consequences include: reductions in agriculture, forestry, and livestock production; damage to infrastructure; alteration of water and nutrient cycles; changes in the availability of clean water; and introduction and spread of new or reemerging diseases. In addition, invasive species can alter disturbance regimes and threaten biodiversity through atypical fire, predation, competition, and disease transmission, often in concert with other invasive species, to cause cascading impacts throughout entire ecosystems (Doherty et al. 2016).

Humans, and their support systems, may be particularly vulnerable to impacts from invasive species. Invasive species are frequently introduced to urban areas or economic centers, where they may influence humans because of their close proximity and relative abundance. Human behavior in urban areas tends to encourage the increase and spread of invasive species, making humans and their support systems even more vulnerable to their impacts. These behaviors include landscaping, clearing native vegetation, and creating disturbed environments in which few species other than invasives can survive.

Costs are incurred in the public and private sectors because of damage to landscapes, animals, infrastructure, and humans, and through management efforts to prevent and mitigate this damage and ensure human safety. Unfortunately, in many cases, these costs have not been quantified. Economic cost data are often not available, and when available, there may be no system in place to summarize or analyze costs. Costs may also be masked within other expenses as a component of larger management initiatives such as habitat restoration. Additionally, there is no direct way to evaluate costs associated with impacts on aesthetics or cultural practices, so estimates of indirect costs or willingness to pay are used. At this point in time it is not possible, even with the best available data, to provide a full accounting of costs related to invasive species (see Chap. 14).

\subsection{Invasive Species and Animal and Human Health}

Animal and human health have been impacted by a wide range of invasive species, including vertebrate animals (mammals, birds, reptiles, fish), invertebrate animals (insects), microbial organisms (fungus, bacteria, viruses), and plant species. These species can affect animals and humans directly by spreading disease or acting as chemical or biological irritants, or indirectly by serving as vectors for invasive or non-invasive organisms that affect health. Invasive species alter the provision of goods and clean water, and may influence safety, as discussed in other sections. Health-related impacts from invasive species may be challenging to prevent when there are lag times between introduction, establishment, and early detection.

\subsubsection{Impacts of Invasive Mammals on Animal and Human Health}

Invasive mammals in the United States include dogs, cats, horses, pigs, and other domesticated animals that were introduced for livestock and pets but have become feral, as well as wild species that were accidentally introduced. The European or black rat (Rattus rattus), Norway or brown rat (Rattus norvegicus), and house mouse (Mus musculus), for example, were unintentionally introduced through trans-Atlantic shipping and other international trade routes (Pimentel et al. 2005).

Rats are known to destroy stored food and grain, damage crops, and prey on poultry, with estimated economic losses of over $\$ 19$ billion per year to the agricultural sector (Pimentel et al. 2000). Moreover, invasive rodents are vectors of serious diseases that infect humans and animals such as salmonellosis, leptospirosis, plague, and murine typhus (Pimentel et al. 2005). Some of these bacterial diseases are directly spread through contamination of feed, food, and water systems; others, like plague, are spread by fleas carried by rodents. The rodent fleas can infect domestic pets which reside in homes, and subsequently transmit disease to humans (Ettestad 2017; Weniger et al. 1984). In addition to their capacity to transmit disease, invasive mammals (rats and feral cats, dogs, and pigs) are considered to be a major 
factor in the extinction of 87 bird, 45 mammal, and 10 reptile species worldwide. These invasive predators also threaten 596 species listed as either vulnerable, endangered, critically endangered, or possibly extinct (Doherty et al. 2016).

Feral and other free-roaming domestic cats (Felis catus), whose populations have been estimated at over 30 million and rising, prey on native birds, small mammals, amphibians, and reptiles (Pimentel et al. 2005). It is estimated that feral cats kill at least 240 million birds each year in the United States (Jessup 2004; Pimentel et al. 2000). The total damage to the U.S. bird population is estimated to be at least $\$ 17$ billion per year when lost recreational costs (hunting, bird watching, etc.) are included (Pimentel et al. 2000). The freeranging behavior of feral cats in shared habitats with native wildlife also predisposes them to exposure to common infections associated with numerous parasites and other transmissible infectious diseases (Jessup 2004). Many of these diseases are zoonotic or capable of infecting humans and domestic animals.

Feral cats can harbor the bacterium Pasteurella multocida, which can be transmitted by cat bites and cause virulent disease in wild birds (avian cholera) and domestic poultry (fowl cholera), and severe infections in humans. Feral cats also are the host for Toxoplasma gondii, a protozoan parasite causing infection in humans and animals in the United States (Dubey 2010; Dubey and Jones 2008). Additionally, Toxoplasma-infected feces can enter coastal waters and cause toxoplasmosis in marine mammals (Barberi et al. 2016; Harris et al. 2002; Miller et al. 2008; U.S. Department of Commerce National Oceanic and Atmospheric Administration 2016).

Feral swine (Sus scrofa) have become established across the United States and have been reported in at least 35 States. Their origins date back to the late 1400s to early 1500s when European explorers and settlers brought their domestic swine to the Americas to serve as a source of food. Free-ranging feral swine populations were established in the United States as a result of open livestock management practices and opportunistic escapes from shooting preserves or commercial farm operations. Subsequent intentional releases of Eurasian wild boar for sport hunting occurred in the 1900s in some parts of the country. Wild boar and domestic swine easily inter-bred, forming additional hybridized populations of feral swine. It is currently estimated that there are over six million feral swine in the United States (Fall et al. 2011).

Feral swine are known to carry at least 30 viral and bacterial diseases such as swine brucellosis (Brucella suis), tuberculosis, leptospirosis, hepatitis (hepatitis $\mathrm{E}$ virus), pseudorabies, and influenza, and nearly 40 parasitic diseases, including toxoplasmosis and trichinosis, which can be transmitted to humans, pets, livestock, and wildlife (Fall et al. 2011; Meng et al. 2009; Witmer et al. 2003). Brucella suis infections were reported in hunters who contracted the disease from feral swine in Florida (Meng et al. 2009). Pederson et al. (2012) found feral swine exposure to brucellosis in 13 States, with exposure rates ranging from $1 \%$ to $14 \%$ of the feral swine population. Swine brucellosis and pseudorabies pose a significant threat to the commercial swine industry, affecting the health and productivity of individual animals resulting in infertility, abortions, lameness in adults, and high mortality in young pigs. The industry spends millions of dollars each year in surveillance and prevention measures dedicated to eradicating disease, supporting animal well-being, and reducing economic impacts attributed to animal mortality (USDA APHIS 2016; Witmer et al. 2003). Feral swine also present a threat for introducing or spreading foreign animal diseases in the United States such as foot-and-mouth disease, classical swine fever, and African swine fever. These foreign agricultural diseases can be introduced either through illegal importation of wild boar from countries where those diseases are prevalent, or by facilitating spread when outbreaks occur in commercial livestock. Swine-adapted influenza viruses also circulate in some feral swine populations that occur in proximity to commercial swine operations. These viruses can be easily transmitted between swine populations and can infect people, as documented in historic and more recent "swine flu" epidemics in the United States and other countries (Miller et al. 2017; Olsen 2002).

Escherichia coli $\mathrm{O} 157: \mathrm{H} 7$ is a virulent strain of bacteria causing severe intestinal and hemorrhagic disease in people (Griffin and Tauxe 1991). Although cattle have been considered a primary reservoir of this bacterium (Hancock et al. 1994), it has been isolated from feral swine feces. In 2006 , people in 26 States and Canada became ill from E. coli O157:H7 after consuming contaminated, bagged baby spinach harvested from feral swine fecal-contaminated agricultural fields in central California (Jay et al. 2007).

\subsubsection{Impacts of Invasive Birds on Animal and Human Health}

Non-native birds introduced to the United States include species such as rock pigeons (Columba livia), English/house sparrows (Passer domesticus), and European starlings (Sturnus vulgaris). Pigeons were intentionally introduced with poultry and livestock in the 1600 s. House sparrows and starlings were introduced in the 1800 s, house sparrows to control canker worm and starlings as ornamental birds. Since introduction, these species have become established throughout the United States and thrive in association with human activities, particularly in urban areas. These birds harbor and transmit more than 50 diseases to humans and other animals, and are common reservoirs for bacterial diseases such as salmonellosis, colibacillosis (E. coli), and chlamydiosis; fungal diseases (histoplasmosis); parasitic diseases (toxoplasmosis); and viral diseases including influenza and West Nile Virus (WNV) encephalitis. For example, Kauffman and LeJeune 
(2011) report that starlings can carry and transmit E.coli O157:H7 to cattle. Humans that consume dairy and beef products from infected cattle may subsequently become infected with the bacteria (Hancock et al. 1994; Kauffman and LeJeune 2011). House sparrows are known to be an important host for WNV, facilitating spread of this introduced vector-borne viral disease (Hayes et al. 2005).

\subsubsection{Impacts of Insect Vectors and Vector- borne Diseases on Humans and Animals}

Vector-borne diseases are transmitted to animals and humans by insect vectors such as muscid flies, mosquitos, ticks, and fleas, typically through bites that introduce infectious pathogens. These vectors can carry pathogenic viruses, bacteria, and parasites and transfer these infectious agents among susceptible hosts. In the United States, there are at least 14 notifiable vector-borne diseases that are threats to national public health and that can cause significant illness and mortality (Beard and Eisen 2016). Several of these, such as Lyme disease and Rocky Mountain spotted fever, have spread to new areas over the past decade, due, in part, to the expanded geographical ranges of their vectors (Beard and Eisen 2016).

Many of these vectors are invasive species. For example, approximately 15 invasive mosquitoes now inhabit Florida, most of which arrived in the past decade. Two new invasive arrivals from Latin America and the Caribbean, Culex panocossa and Aedeomyia squamipennis, were just detected near Everglades National Park in late 2016 (Blosser and BurkettCadena 2017). These mosquitoes are suspected vectors of Venezuela equine encephalitis virus, which can cause fatal infections in humans, horses, and other animals. In Hawaii, a State with no native mosquito species, the introduced Culex quinquefasciatus mosquito spread quickly, vectoring avian malarias that have devastated Hawaii's native bird populations (van Riper et al. 1986).

Other vector-borne diseases have recently been reported in the United States, including WNV, dengue, chikungunya, and Zika virus. These diseases have been introduced to the United States either through infected travelers carrying the disease or the inadvertent movement of invasive vectors inside international cargo containers. Once in the United States, competent vectors may spread diseases further by infecting susceptible hosts. For example, the yellow fever mosquito, Aedes aegypti, which originated in Africa and has been reported in Florida, along the Gulf coast, and the Washington, D.C. region, can carry and transmit more recently arrived pathogens such as those that cause dengue, chikungunya, and Zika virus.

\subsubsection{Impacts of Microbial Pathogens on Animals}

White-nose syndrome (WNS) is a lethal fungal disease prevalent in North American bats and caused by an introduced non-native fungus, Pseudogymnoascus destructans $(P d)$. WNS was first reported in upstate New York in 2006, and has since spread to 30 U.S. States and five Canadian provinces. The $P d$ fungus is a cryophilic (cold-loving) species originating in Europe and Asia. It thrives in cave environments and is thought to have been introduced into the United States through international recreational caving activities. Models suggest that WNS will eventually spread across the entire United States (Maher et al. 2012) since cave climatological data indicate sufficient microclimates exist for growth of the fungus throughout North America (Perry 2013).

WNS has been found in nine species of hibernating bats in North America, with mass mortality and significant population declines primarily in the little brown bat (Myotis lucifugus), northern long-eared bat (Myotis septentrionalis), Indiana bat (Myotis sodalis), and tri-colored bat (Perimyotis subflavus) (Turner et al. 2011). In 2012, the U.S. Fish and Wildlife Service and collaborating scientists estimated that up to six million bats had died from WNS since 2006 (Reeder et al. 2012; Turner et al. 2011). Due to severe population declines due to WNS, the northern longeared bat was listed in 2016 as endangered. Bats are important in sustaining healthy forest and agricultural ecosystems, and provide many ecosystem services benefits to humans, including crop pollination and insect control (Boyles et al. 2011; López-Hoffman et al. 2014). Tourism associated with bat-viewing has been estimated to contribute $\$ 6.5$ million annually to some local economies (Bagstad and Wiederholt 2013).

Another invasive and infectious fungal disease, chytridiomycosis, has been spreading globally for many decades causing worldwide declines and extirpations of amphibian populations. Chytridiomycosis is caused by the chytrid fungus, Batrachochytrium dendrobatidis $(B d)$, which has been linked to the commercial exportation of African clawed frogs (Xenopus laevis) for use in research, human pregnancy testing, and the pet trade. More recent evidence suggests that cycling weather patterns (flooding, hurricanes, the El Niño Southern Oscillation) also may have contributed to spread of this virulent disease (Daszak et al. 2000; Kolby and Daszak 2016). A closely related pathogenic fungus, Batrachochytrium salamandrivorans (Bsal), has emerged recently in Europe and is causing widespread mortality in salamanders. Although not yet reported in the United States, major concerns exist for its potential intro- 
duction into North America, and the risk of causing catastrophic losses to native U.S. salamander species, including many species likely susceptible to Bsal (Grant et al. 2016; Martel et al. 2013; Yap et al. 2015).

\subsubsection{Impacts of Invasive Plants on Animal and Human Health}

Invasive plants can affect animal and human health by providing habitat for vectors of disease. For example, Japanese barberry (Berberis thunbergii) was introduced into the United States in the late 1800 s as an ornamental plant and promoted as a replacement for the common barberry (Berberis vulgaris). Now present in over 30 States and four Canadian provinces, it forms dense stands or thickets favorable to blacklegged/deer tick (Ixodes scapularis) populations (Elias et al. 2006; Williams and Ward 2010). Deer ticks are a key vector for Lyme disease in humans and animals, caused by the bacterial spirochete Borrelia burgdorferi (Beard and Eisen 2016).

Other invasive plants cause harm to humans through direct contact, causing irritation to the skin or other tissues. For example, giant hogweed (Heracleum mantegazzianum) was imported from the western Caucasus area into Europe and North America as an ornamental plant due to its immense size. However its milky sap can cause severe dermatitis, much like poison oak (Toxicodendron diversilobum) and poison ivy (Toxicodendron radicans) (Jones and Russell 1968). The sap of tree of heaven (Ailanthus altissima) can cause myocarditis (an inflammation of the heart muscle) in humans (Bisognano et al. 2005). In addition, the architecture of some invasive plants can cause harm, as large thorns may rip skin or clothing. An infestation of yellow star-thistle (Centaurea solstitialis) may effectively eliminate an area from any use or activity, such as grazing, recreational activities (such as hiking or birding), and military purposes (see Sect. 9.3.3).

\subsubsection{Next Steps in Management and Mitigation of Invasive Species for Animal and Human Health}

Global travel and trade, international movement of livestock, translocation of wildlife and pets, modern agricultural practices, and changing climate patterns have led to the introduction of non-native invasive vertebrate and invertebrate animal, plant, and microbial species, and the emergence of novel infectious diseases across North America and other continents. Expansion of the geographic range of invasive species and introduced diseases arises from changes in the inter-relationships between the native host, invasive pathogen, and the local environment or ecosystem. Intervention in one or more of these factors can disrupt or prevent the disease cycle. The same integrated approach can apply in developing control strategies to disrupt the life cycles of invasive species. Multi-disciplinary investigations are needed into the ecology, disease transmission and pathogenesis, and population biology of invasive species and introduced diseases to identify underlying causes and ways to prevent spread (Daszak et al. 2000).

In addition, collaboration across Federal, State, local, and tribal governments; stakeholders; and the private sector can help minimize and mitigate the spread of invasive species. Research is needed to develop new technologies and methods that enhance early detection and rapid response to eradicate or control invasive species and restore native species and ecosystems. Increased efforts to promote public education, address regulatory gaps, and coordinate with national and foreign governments to prevent introduction, minimize movements, and address impacts of invasive species may also be effective. Since many health impacts begin with local invasions, either intentional or inadvertent, actions by individual citizens and local communities to prevent, mitigate, and eradicate invasive species may be particularly effective.

\subsection{Invasive Species and Military Readiness}

Invasive species impact military operations directly and indirectly through effects on combat readiness; human health, as discussed above; and recovery efforts for threatened and endangered species. Military personnel conduct crucial training, testing, and operational activities in air, land, and aquatic landscapes that must be managed and maintained for mission readiness. The Department of Defense (DoD) manages approximately 25 million acres of land encompassing over 420 large installations, of which 342 have natural resources significant enough to require management under the Sikes Act (DoD 2017). Access to DoD lands is often restricted, resulting in undisturbed areas that harbor rare and sometimes unique habitats. In fact, DoD lands have higher levels of biological diversity and more sensitive species per acre than other Federal lands (NatureServe 2015). Invasive species can have significant detrimental effects on these sensitive habitats. In addition to the impacts on natural resources, invasive species can affect testing, operational, and training activities; military personnel health, security, and installation infrastructure; and global movement of personnel and equipment that can and do result in land use restrictions and added expenses for DoD. 


\subsubsection{Operational Impacts Due to Invasive Species}

\subsubsection{Impacts on Military Personnel Health}

Safety and health of military personnel and operations can be significantly impacted by invasive species in a variety of ways. Invasive species can cause injury, transmit disease-causing pathogens, and serve as a refugia for vectors, hosts, and pathogens. They may interfere with safety and security by obscuring unexploded ordnance, serving as fuel for wildfires, and impeding lines-of-site monitoring for security forces personnel. For instance, military personnel and dogs have been attacked by invasive feral swine. Soldiers have also been injured with burns and temporary blindness caused by contact with giant hogweed during training operations. Red imported fire ants (Solenopsis invicta) and recently little fire ants (Wasmannia auropunctata) in the Pacific can cause intense burning and swelling through their mass biting/stinging, and may also seriously injure, blind, or kill sensitive animals. Invasive plants such as honeysuckles (Lonicera spp.) and barberries (Berberis spp.) serve as refugia for infected ticks that transmit diseases to military personnel (Dalsimer 2002).

The $\mathrm{DoD}$ is very concerned about introducing disease pathogens and their reservoirs, as well as arthropods that may vector diseases (see Sects. 9.2.3 and 9.2.4). Introductions of invasive diseases can impact local and deployed forces, and require significant surveillance, testing, and control measures at affected installations (DoD AFPMB 2016). The 2016 Zika outbreak in the New World interfered with missions, and resulted in country clearance burdens requiring aircraft disinsection (spraying aircraft for insects) to eliminate potential mosquito vectors.

\subsubsection{Impacts on Personnel and Operational Safety}

Invasive species and wildlife management is essential around training ranges and airfields to protect aircrews and aircraft and ensure safe military flight operations as these can attract birds and other wildlife that pose bird/wildlife aircraft strike hazards (DoD 2017). In addition to impacting flight operations, invasives also can damage runways, infrastructure, and surrounding areas. Managing for invasives in and around airfields and training ranges is a DoD priority.

Invasive plants, such as the common reed (Phragmites spp.) in wetland habitats at several military installations along the Chesapeake Bay, not only affect wildlife but can obscure clear lines-of-sight, thus threatening base security. The DoD actively manages Phragmities through targeted herbicide spraying and reseeding with native plants to limit common reed growth and expansion (DoD 2011).

Invasive insects that cause tree mortality also create safety hazards from falling trees until dead trees can be removed. The invasive coconut rhinoceros beetle (Oryctes rhinoceros) bores holes into crowns of coconut and other palm trees (Arecaceae), often resulting in widespread tree mortality and interference with training operations in Hawaii and Guam. In Hawaii, the DoD is collaborating with the U.S. Department of Agriculture, Animal and Plant Health Inspection Service (USDA APHIS), State of Hawaii Department of Agriculture, and the University of Hawaii to eradicate the coconut rhinoceros beetle from Hawaii through an integrated program that includes population monitoring, removal of breeding sites, and public outreach and education campaigns (HDOA 2016).

\subsubsection{Environmental Impacts of Invasive Species on Defense}

\subsubsection{Impacts to Threatened, Endangered, and At-risk Species}

Approximately 60 listed species and over 70 species at risk of needing listing protection occur only on DoD lands, which harbor a higher density of sensitive species than on any other federally managed lands (NatureServe 2015). DoD strives to prevent and control the introduction, spread, and establishment of invasive species which can have devastating effects on sensitive species. For instance, DoD manages invasive feral swine through monitoring, hunting, trapping, and public outreach and education to help prevent the swine from destroying nesting habitats, eating endangered plants, and damaging infrastructure and training lands. Another example is at Marine Corps Base Hawaii where the military conducts amphibious vehicle training in mudflats invaded by pickleweed (Salicornia spp.). The activity not only breaks up and destroys the pickleweed, but helps protect the endangered native Hawaiian stilt (Himantopus mexicanus knudseni), which nests in the mudflats, by creating additional nesting habitat (U.S. Marine Corps 2001).

\subsubsection{Impacts on Wildfire}

Invasive grasses, including fountain grass (Pennisetum setaceum) in Hawaii and cheatgrass (Bromus tectorum) in the Western United States, have become the dominant ground cover on many military installations. Species composition is dramatically altered following invasion by these grasses which creates wildfire-friendly conditions in ecosystems that are not wildfire adapted (Coates et al. 2016).

Uncontrolled wildfires threaten the safety of military personnel and their families. Wildfires pose a risk to infrastructure and degrade testing and training lands, and may spread beyond military boundaries to local communities. These fires are expensive to control and mitigate. In addition, smoke and atmospheric particulate matter negatively impact air quality and can inhibit training activities and military flight operations (DoD 2017). 
The DoD is actively engaged in managing both invasive species and wildfire. Military natural resource managers use prescribed fire to reduce or clear excess vegetation including cheatgrass, halogeton (Halogeton spp.), musk thistle (Carduus nutans), salt cedar (Tamarix spp.), tumbleweed (e.g., Kali spp.), and Sahara mustard (Brassica tournefortii) to support recovery of fire-tolerant native species such as longleaf pine (Pinus palustris) (Sustainable Fort Bragg 2017).

\subsubsection{Economic Impacts on Defense}

\subsubsection{Mitigation Costs}

Invasive species surveillance, prevention, management, and control are integrated in a variety of DoD programs including Operations, Training, Pest Management, Natural Resources, and Morale and Welfare. Collectively, DoD invests significant resources into managing and mitigating invasive species. For instance, Marine Corps Base Camp Pendleton in southern California spent approximately $\$ 1.2$ million over a 5-year period to control invasive species that could have severe impacts on infrastructure, native ecosystems, and training activities (DoD 2017). The Navy also invests considerable funds by implementing voluntary adoption and application of U.S. Coast Guard guidelines for controlling ship ballast water to prevent the introduction of invasive aquatic organisms into U.S. waters. Similarly, the fee-for-service military agricultural pre-clearance inspection program (Defense Transportation Regulation 2018a, b) helps to prevent accidental introduction of invasive species, and facilitates the safe return of military personnel, vehicles, equipment, and cargo from locations around the world.

To avoid the inadvertent introduction of invasives when moving equipment, vehicles, and supplies for military and humanitarian relief activities, DoD implements costly management practices including utilizing cleaning facilities and equipment, and having plant and pest quarantine officers inspect military equipment and personnel (DoD AFPMB 2017). Inspections and cleanup operations are performed in partnership with USDA APHIS, and are intended to prevent the transport of non-native animal and plant pests. In addition, DoD has phytosanitary regulations (e.g., DoD 4149.01M-1) for wood packing materials (WPM) to prevent introduction of pests through transport of uninspected WPMs used in shipping (DoD 2017).

\subsubsection{Lost Capability Costs}

Invasive species also have indirect economic impacts through lost capability, including limiting field maneuvers and training exercises. For instance, several years ago, parachute training had to be halted at Fort Hunter Liggett, CA due to a severe infestation of yellow star-thistle in a parachute drop zone, which would have injured soldiers, snagged and torn their parachutes, and clogged vehicle air filters. The Fort used an integrated pest management strategy incorporating hand pulling, mowing, herbicide treatment, and biological control that significantly reduced yellow star-thistle density on about 10,000 acres. Costs for control and alternative protocols to continue mission activities were substantial (DoD 2011). Whenever invasive species interfere with operational activities, costly workarounds must be implemented to ensure that military personnel can sustain mission readiness.

\subsubsection{DoD Invasive Species Management}

\subsubsection{Policy and Guidance}

The DoD's policy and guidance related to invasive species management focuses on Pest Management, Operations and Maintenance, and Natural Resources programs. DoD provides policy and guidance to (1) prevent the introduction of invasive species; (2) detect and respond rapidly to, and control populations of such species using integrated pest management (IPM) techniques; (3) monitor invasive species populations accurately and reliably; (4) restore native species and habitat conditions in ecosystems that have been invaded; (5) conduct research on invasive species, develop technologies to prevent introduction, and provide the latest IPM techniques for their control; and (6) promote public education on invasive species (DoD 2017). The Military Services also comply with Executive Order 13751, Safeguarding the Nation from the Impacts of Invasive Species (No. E.O. 2016).

DoD natural resources managers control invasive species by implementing integrated pest management plans, which focus on identifying and monitoring pests, pathogens, and insects; setting action thresholds; and preventing and controlling pests. Integrated Natural Resources Management Plans (INRMPs) are used to guide how military installations will manage their natural resources, including control of invasive species. Installations are required to identify, prioritize, monitor, and control invasive and noxious species and feral animals whenever feasible (DoD 2018). In addition, DoD requires that native species be used, where feasible, to restore habitats impacted by invasive species. Installations endeavor to conserve and protect water resources, use locally adapted native plants, avoid using invasive species, and minimize the use of pesticides and supplemental watering.

\subsubsection{Managing Invasive Species Through Biosecurity Plans}

Increasingly, the DoD is using biosecurity plans as a means of addressing mission impacts associated with invasive species often in conjunction with Endangered Species Recovery 
efforts. For instance, the Department of the Navy developed a regionally vetted plan called the Regional Biosecurity Plan (RBP) for Micronesia and Hawaii to guide relocation of U.S. Marine Corps personnel to Guam, and invested nearly $\$ 4$ million to proactively address regional concerns about the risks of invasive species to terrestrial, freshwater, and marine environments. The RBP was produced in cooperation with the U.S. Geological Survey, Smithsonian Environmental Research Center, National Invasive Species Council, University of Guam, and USDA APHIS and assesses invasive species risk pathways with a focus on threats from the coconut rhinoceros beetle, brown tree snake (Boiga irregularis), and other serious invasives in the Pacific (University of Guam and the Secretariat of the Pacific Community 2014). The Department of the Navy has also implemented an invasive species-focused biosecurity plan for Naval assets on San Clemente Island in California (DoD 2017), Hawaii, and other locations.

\subsection{Invasive Species Effects on Urban Plant Communities, Infrastructure, and Safety}

Urban areas are the epicenter of many, if not most, nonnative plant, insect, and pathogen invasions (Alston and Richardson 2006; Smith et al. 2006). Urbanization and the import of plant species for landscaping are directly linked. Most imported plants are non-native and some may become invasive, potentially spreading into surrounding rural and natural areas (Duguay et al. 2007; Guo et al. 2006; McDonald et al. 2008).

Invasive plants may change the community structure of the natural vegetation in urban areas such that native species are less dominant (Lambrinos 2000). They may alter nutrient cycling or add novel allelopathic compounds to the soil, resulting in disturbed conditions that favor further invasion and deter re-establishment of native species (GomezAparicio and Canham 2008a; Murrell et al. 2011; Stinson et al. 2006). Such changes in ecosystem (Ehrenfeld 2003; Gomez-Aparicio and Canham 2008b) and disturbance (Mack and D'Antonio 1998) processes may occur anywhere along the urban-rural interface. Urbanization also produces disturbed open areas subject to invasion (Alston and Richardson 2006), heat islands (Botkin and Beveridge 1997; Oke 1995; Pickett et al. 2001), impervious surfaces, and toxic soils (Cannon and Horton 2009; Gill et al. 2007; Leishman and Thomson 2005) that only a few, often non-native, plants can tolerate.

Urban residents value the decorative nature of many nonnative plant species, and the sale of these plants and landscaping costs associated with their planting and maintenance can be a key component of urban and suburban economies, including housing valuation and landscaping, and other businesses associated with horticulture and supplying plants (Des Rosiers et al. 2007; Drew et al. 2010; With 2002). According to the U.S. Census of Horticulture Specialties, there were over 23,000 horticulture operators in 2014 that conducted about $\$ 13.8$ billion in sales, and approximately 12,400 of these operators were in the floriculture sector, which conducted $\$ 5.9$ billion in sales (USDA National Agricultural Statistics Service 2014). Of course, not all horticulture sales are of non-native plants, and not all non-native plant sales pose a risk of invasion. Unfortunately, there are substantial difficulties associated with identifying which non-native plants will become invasive and managing a highly disaggregated industry. Controlling risk associated with commercial horticulture and nurseries, therefore, requires balancing the risk of invasion with the benefits people derive from non-native plants (Knowler and Barbier 2005).

Invasive insects and diseases may be inadvertently imported with landscaping plants or other imported goods, damaging both native and non-native plant communities. Invasive plants, insects, and animals can harm the built environment, incurring public and private costs for repair and replacement, and presenting safety risks to urban residents.

\subsubsection{Invasive Species and Urban Plant Community Composition}

When regionally distinct native communities are replaced with locally expanding, non-native communities with no barriers to expansion, there may be homogenization of species (Collins et al. 2002; McKinney and Lockwood 1999; Olden and Rooney 2006). The result is that one urban area often shares many of the same plant species with other urban areas. Although these urban areas may share many of the same non-native plants, they may still have a rich flora of different, albeit rare, native species that could be maintained (Kowarkik 2011; Schwartz et al. 2006).

Possibly, homogenization in the United States may not be fully realized since the oldest cities are only a few centuries old (Clements and Moore 2003; Lososova et al. 2012). A study of native and non-native flora of Boston; New York; Philadelphia; Washington, D.C.; Detroit; Chicago; Minneapolis; and St. Louis found that those cities only shared $7.5 \%$ of their non-native species. They also only shared $11.6 \%$ of their native species, with distinct East Coast and Midwest city clusters, suggesting geography still plays an important role in defining species compositions in these urban areas (Clements and Moore 2003). A study of 110 cities worldwide found that the majority of urban plant species were still native; however, their densities had declined substantially to $25 \%$ of the overall density of all plant species. 
This change in density is correlated most strongly with land cover and city age (Aronson et al. 2014).

Phylogenetic diversity, or differences in evolutionary origin, of non-native plants is lower than that of native plants, both within single cities and across cities; phylogenetic diversity is even lower for non-native species with residence times of multiple centuries. Non-native species in the United States are significantly overrepresented by six families: Boraginaceae, Brassicaceae, Fabaceae, Caryophyllaceae, Chenopodiaceae, and Solanaceae (Ricotta et al. 2009). Functionally related species often share a common origin and phylogenetic history, suggesting that limited phylogenetic diversity equates to limited functional diversity (Darwin 1859). Thus, low functional diversity may limit the range of ecosystem services that non-native species in urban areas can provide.

Globally, pollinator declines are attributed to habitat loss associated with urbanization. Nonetheless, there is empirical support suggesting that non-native entomophilous plants (reliant on insects for pollination) are easily integrated into existing native plant-pollinator networks, acting as additional or in some cases the only sources of pollen and nectar. Thus, non-native plants (including entomophilous invasive plants) may serve to keep pollinator populations viable (Potts et al. 2010; Stout and Morales 2009). Unfortunately, this pollination "buffer" may only benefit generalist pollinators. Many native species interact with specialist pollinators; consequently, displacement or reduction in abundance of these native plants by non-native species also leads to a subsequent reduction in specialist pollinators (Traveset and Richardson 2006).

\subsubsection{Effects of Invasive Insects and Disease on Urban Plant Health}

Previous chapters have described the effects of invasive insects and disease on forest and grassland communities, but they can also affect urban areas. Urban forests and trees provide critical benefits such as helping filter air and water, controlling storm water, conserving energy, and providing animal habitat and shade. They also reduce noise, provide places to recreate, support mental health, and add economic value to our communities. According to Nowak et al. (2002), the total value for urban forests in the contiguous United States is about \$2.4 trillion. They place the value of New York City's urban forest near $\$ 5.2$ billion. These estimates are based on compensatory values, the value homeowners would have to be paid to be as well off should one of their trees be removed. These values largely reflect the cost of replacing the tree (purchasing a new tree and having it planted). A broader look at values associated with urban trees is given in Roy et al. (2012), which reviews 115 urban tree studies. Many of the papers reviewed discuss the role of trees in making the urban environment more pleasant, in increasing property values, in providing shade and wind protection, and in lowering energy costs. Many also address the costs associated with trees, including prevalence of pollen allergies, release of volatile organic compounds, and reducing solar access. One study in Minnesota found that a $10 \%$ increase in tree cover within $100 \mathrm{~m}$ of a home increases the home's sale price by about $\$ 1400$ (Sanders et al. 2010). Donovan and Butry (2009) found that tree cover on the west and south sides of houses in their sample resulted in a $5 \%$ reduction in summertime electricity use.

With overarching branches that create beautiful shaded canopies, elm trees (Ulmus spp.) are well suited as street trees, and they have been planted in rows along streets and walkways of large cities and small towns across North America. The uniformity of these monocultures is not only aesthetically pleasing but efficient from the standpoint of nursery production, planting, and maintenance. However, these monocultures are susceptible to insects or pathogens that can invade and quickly move through the area. Dutch elm disease, caused by the invasive fungi Ophiostoma ulmi and Ophiostomoma novo-ulmi, has spread rapidly through urban areas and produced severe damage to vegetation. Not only is the invasive pathogen able to quickly colonize the native host, but it is able to efficiently move to neighboring trees because it is vectored by the non-native European elm bark beetle (Scolytus multistriatus), whose populations exploded with the abundance of dying host material. When the Dutch elm disease fungus was first introduced into North America around 1930, there were approximately 77 million elms in cities and towns across North America; however, by the 1970s, only about 34 million elms survived. The costs of removal of many dead elms and of protection of the remaining trees has had a significant economic impact on municipalities and homeowners.

A historical analysis of the economic impacts of nonnative forest insects by Aukema et al. (2011) found that homeowners and local governments bear the largest costs from invasive insects. Local government expenditures for management, and residential property value losses were the two highest cost categories. Additionally, they found that woodborers were consistently the most economically damaging insect feeding guild. Nowak et al. (2002) found that in select cities, the potential tree losses from the Asian longhorned beetle (Anoplophora glabripennis) ranged from $12 \%$ to $61 \%$ of city tree populations with an estimated value of $\$ 72$ million to $\$ 2.3$ billion per city. As of the end of 2016 , Asian longhorned beetle infestations were being managed by USDA in New York, Massachusetts, and Ohio. In an effort to eradicate this non-native woodborer in Massachusetts and Ohio, more than 40,000 host trees have been removed from 
these two States since 2008 and 2011, respectively (USDA APHIS 2017).

Perhaps the invasive insect with the most significant impact in urban areas is one of the most recently established species, the emerald ash borer (EAB) (Agrilus planipennis). This woodborer, native to Asia, was first found in the Detroit, MI-Windsor, Ontario area in 2002 but was likely introduced five to 10 years prior to then (see Chap. 7 for details on EAB biology and management). As with Dutch elm disease, EAB moved rapidly along city streets and caused extensive mortality where ash trees (Fraxinus spp.), especially green and white ash (Fraxinus pennsylvanica and Fraxinus americana) and their cultivars, were commonly planted in monocultures as elm replacements in the aftermath of Dutch elm disease. It is estimated that 100 million ash trees in both rural and urban landscapes have been killed by EAB, but perhaps the greatest economic impact has been realized in urban forests. A 2009 estimate of the potential cost of EAB treatment, removal, and replacement in urban communities over a 10-year period was $\$ 10.7$ million (Kovacs et al. 2010). Simulations in this study were based on EAB expanding to 25 States between 2009-2019 and affecting 17 million ash trees. As of the spring of 2020, EAB was found in 35 States (USDA APHIS 2020).

The management of EAB in North America highlights some of the challenges faced when dealing with a new invasive. Very little was known about EAB prior to 2002, even in the Asian literature. Research in North America basically had to start from scratch to understand EAB biology, life cycle, host relationships, and population biology. One of the greatest challenges was to develop tools to effectively survey for this insect. Although regulations were quickly established to limit the movement of $\mathrm{EAB}$, it became readily apparent that infestations had already spread beyond the known infested area. As these isolated infestations developed, the beetles again were unknowingly spread to additional locations. In many cases it was determined that $\mathrm{EAB}$ was in an area for 3-5 years before being detected.

Across North America, other invasive insects and pathogens have had economic and social impacts in the urban environment. Although some of these invasive species, such as chestnut blight (Cryphonectria parasitica) and gypsy moth (Lymantria dispar dispar) have had greater impacts in natural forests, they also have impacted urban and suburban forests (see Sect. 9.8). In the Western United States, the walnut twig beetle/thousand cankers disease complex (Pityophthorus juglandis and Geosmithia morbida) and the shothole borer (Euwallacea spp.)/Fusarium species complex have recently caused significant local impacts on urban forests. In the Eastern United States, bacterial leaf scorch (Xylella fastidiosa) has reportedly caused gradual mortality of a number of different species of urban street and park trees (see Chap. 2).

\subsubsection{Impacts on Urban Safety and the Built Environment}

Unless removed, dead and dying trees damaged by invasive species can be extremely hazardous in the urban environment. Limbs and even whole trees can fall on roads, houses, cars, and power lines, destroying property and threatening human safety. Dead trees and invasive grasses, such as cheatgrass and buffelgrass (Pennisetum ciliare) (Balch et al. 2013), may elevate the risk of wildfire, particularly in drought years, affecting open spaces in western cities such as Denver and Boulder, CO. The National Storm Damage Center estimates that trees cause about $\$ 1$ billion in property damage each year attributed to severe weather.

Invasive species may also cause harm to the built environment (ISAC 2016). English ivy (Hedera helix) can root in the grouting between masonry, destroying the structural integrity of brick structures over time, while African land snails (Achatina fulica) can eat the concrete stucco of buildings (ISAC 2016). The Formosan termite (Coptotermes formosanus) has also caused significant damage to structures in the United States. It can enter buildings from the ground through cracks, joints, and utility conduits, and can even maintain colonies on flat rooftops (Su and Scheffrahan 2016); once established it consumes cellulose in wood. Prevention, control, and repair of structural damage is estimated to cost consumers over $\$ 1$ billion per year (Lax and Osbrink 2003).

Invasive birds and mammals may cause additional damage to structures. Birds can leave droppings, crack windows, bore into wood, and build nests that may be a nuisance. Control costs for rock pigeons are estimated at $\$ 2$ billion per year in the United States (Pimentel et al. 2005). Norway rats can live below building foundations and inhabit walls, cellars, and lower floors of buildings; their gnawing and burrowing can damage the wood and insulation of the buildings and undermine the foundations (Timm 1994).

\subsubsection{Management Options}

Urban areas are not as conducive to management tools often used in rural and natural areas, such as fire, pesticides, poison baits, addition of top predators, and fencing to reduce herbivory. Eliminating pests and managing for native species will entail increased engagement of community members (Dearborn and Kark 2009), which may be facilitated through public education and volunteer engagement programs, including those that engage community members in restoration and citizen science. Local arboreta and public and private botanical gardens can often be of assistance, providing both education and local expertise to the community.

Urban areas could potentially avoid homogenization or a loss of native species densities through planting of native 
species (preferably, historically common to the area or locally suitable), reducing the presence of invasive species, and applying a landscape-level approach to urban planning. A landscape approach might involve establishing interconnecting gardens dominated by native and/or non-invasive non-native plants via corridors, such as utility rights-of-way, road medians, subdivision entry displays, and walking paths. This scaling up from the garden to the neighborhood, and finally to a city-wide landscape of connected gardens, parks, and planted corridors, requires cooperation among a range of stakeholders across all sectors of society (home owners, city planners and parks departments, and housing developers). Such collaboration is often only possible when economic incentives (e.g., resulting increase in property value) or measurable ecosystem services (e.g., improved community health and well-being) (Goddard et al. 2009; Ignatieva et al. 2011) are provided.

Researchers have begun developing provisional seed zones for native species (Bower et al. 2014). Having seed zones established for native species, especially those that are nested within an ecoregion and include more detailed species-specific fitness (growth and reproductive) responses over an environmental gradient, will enable urban planners and individual city dwellers to select native species that are genetically and ecologically suitable to their site. More importantly, they could select species that can survive within a relatively broad environmental gradient and would therefore be less vulnerable to changes in temperature or precipitation, and to invasive species (Havens et al. 2015).

Urban areas can limit impacts of invasive plants if the remnant ecosystems are managed sustainably. Managers can actively remove invasive species and avoid practices that create openings suitable for invasive species, such as harvest and prescribed fire, or involve equipment that might aid the spread of invasive species. Successful regeneration of native species after removal of invasive species has had mixed success (Kettenring and Adams 2011) and may require active control of other factors, such as excessive deer herbivory (Huebner et al. 2010), toxic runoff from adjacent impervious surfaces (Gill et al. 2007; Leishman and Thomson 2005), new insects and pathogens introduced with non-native landscape plants (Liebhold et al. 2012), soil compaction, urban air pollution and nitrogen/sulfur and ozone deposition (Nowak 2010; Ziska et al. 2004), and urban heat (Pickett et al. 2001). Many people are supportive of planting native species preferentially over better-known non-natives as long as they are aware of the native species, can purchase them, and can control where they plant them (Doody et al. 2010). Thus, educating the public about native species that are available for them to plant instead of non-native species is just as important as educating them about the potential negative impacts of non-native plants. The City of Portland, OR, for example, publishes a plant list of native plants that homeowners and landscapers are encouraged to use, and a list of nuisance plants that people are encouraged not to plant and that are prohibited on city grounds and projects (Bureau of Planning and Sustainability 2016). In some instances, cities may opt to quantify costs associated with invasive species in an effort to incentivize businesses not to sell potentially profitable invasive plants.

As non-native plant imports are the major source of inadvertent introductions of invasive insects and pathogens (Liebhold et al. 2012), use of native species in urban green spaces will also decrease the abundance of invasive insects and pathogens in urban areas. Once established, the impact of insects and pathogens can be substantial, and management actions required to reduce such impacts will be required. In urban areas, the management of Dutch elm disease usually is accomplished in one of three ways: reduction of the bark beetle vector populations, prophylactic protection of elms with fungicides, or the long-term use of breeding for host resistance. Large-scale treatment of elms with insecticide spraying produced significant ecological impacts, and for the most part has been abandoned (Karnosky 1979). The use of bark beetle trap trees along with pheromone-baited traps has shown promise (Lanier 1989) but has not been utilized widely.

Perhaps what has proven to be the most effective strategy for most municipalities is the diligent surveillance and removal of infected trees or branches. Scouting to identify new infections, followed by timely pruning of infected trees, or injections of fungicides to stop spread within a tree, have proven to be very cost-effective. Sanitation, or the rapid removal of beetle- and disease-infested trees, is also an integral component of effective management. Cities such as Washington, D.C. and Winnipeg, Canada still have extensive elm populations due to their utilization of integrated management programs. Although it is expensive for municipalities to sustain effective management programs (Winnipeg spends approximately $\$ 3$ million annually), it is still less costly than the city-wide removal of large, dead trees (Pines 2009).

\subsection{Impacts of Invasive Species on Water Resources and Systems}

Globally, human use of freshwater surpasses long-term supplies by approximately $25 \%$; this is possible due to water transfers between watersheds and extraction of groundwater supplies (Catford 2017). Invasive plants, vertebrates, and invertebrates can alter water supplies by altering water courses via accretion or clogging of waterways, or increasing evapotranspiration rates; invasive species also impede human use of water systems through eutrophication, altera- 
tion of sediments, fouling, and impeding access. Therefore, a key concern attributed to invasive species in the United States is the potential reduction of available and usable water resources. Concern about these impacts is increasing because predicted global climate change is anticipated to alter patterns of discharge and temperature, potentially enhancing habitat for invasive species rather than for native species, further exacerbating the economic effects of invasive species management and remediation.

\subsubsection{Impacts of Invasive Species on Water Quantity}

As the human population continues to increase in the United States and globally, water demands for irrigation, drinking, and other household uses will continue to rise. This is particularly challenging in areas that face frequent droughts and water shortages, such as California, an increasingly populated state. The July 2016 estimated population of California was 39.4 million and is projected to grow by $0.76 \%$ annually, or 6.5 million additional people by 2036 (California Department of Finance 2017). This will place even higher demands on water infrastructure.

Invasive plants are a particular concern because they can reduce freshwater availability through high rates of transpiration. For example, saltcedar (Tamarix spp.), originally introduced to North America as nursery stock in the $1800 \mathrm{~s}$ (DiTomaso 1998), is now common in the Southwestern and interior Northwestern United States (Kerns et al. 2009). Although there have been studies that document high rates of water use by native plants (Cohn 2005), some have found that saltcedar uses significantly more water than native species ( 1.4-3.0 billion $\mathrm{m}^{3}$ annually), at an estimated cost of \$26.3-\$67.8 million dollars in water that could be used for agriculture, drinking water, or hydropower (Pejchar and Mooney 2009; Zavaleta 2000). A large saltcedar tree can uptake $760 \mathrm{~L}$ of water in a single day, leading to desiccation of streams and springs, potentially lowering the water table and limiting water supplies to native species (DiTomaso 1998 and references therein). While saltcedar was originally marketed as an ornamental shrub, it was also used for windbreaks and to stabilize eroding stream banks. In places, the dense and stable root architecture of salt cedar exceeds that of native riparian species, leading to immobilized channels with increased sediment deposition. This process gradually restricts channel width and increases flow rates, which enhances flooding and promotes dispersal of invasive species further away from the stream bank (DiTomaso 1998).

Tall-statured grasses such as the giant reed (Arundo donax) and the common reed have significantly altered wetlands in North America (Zedler and Kercher 2010). Both species readily spread via clonal rhizome fragments, grow in near monocultures (outcompeting native plants), use the $\mathrm{C} 3$ photosynthetic pathway, which makes them less efficient in their use of water than $\mathrm{C} 4$ grasses, and produce highly flammable aboveground biomass, thus making them a fire hazard (Bell 1997; Meyerson et al. 2000). Giant reed colonizes arid regions such as southern California, where its high rate of water consumption (nearly $9 \mathrm{~mm}$ of water per day in one study (i.e., Watts and Moore 2011) and 1700 mm/year in another (i.e., Iverson 1998)) further reduces water availability and exacerbates drought conditions. The common reed is among the most widely spread and best-studied species globally, and is highly invasive in both freshwater and brackish wetlands (Meyerson et al. 2016). This invasive wetland plant has transformed wetlands into uplands because of its high productivity and production of slowly decomposing biomass, which acts as a significant barrier to water accessible for recreation. Martin and Blossey (2013) estimated that over a 4-year period in the United States, nearly \$20 million dollars were spent on common reed control (often with pesticides) with limited success at eradication.

In Hawaii, invasive species may exacerbate already significant reductions in freshwater supply. Computer models that simulate changes in water yields on the Big Island of Hawai' $i$ found that stream flows could be reduced by $50 \%$ due to climate change, and project an additional $2 \%$ loss due to invasive species such as strawberry guava (Psidium cattleianum) and invasive ginger (Hedychium gardnerianum) (Ayron et al. 2016).

\subsubsection{Impacts of Invasive Species on Infrastructure and Water Quality}

Invasive aquatic invertebrates may be particularly problematic for human water infrastructure. Invasive Dreissenid mussels, which include the zebra mussel (Dreissena polymorpha) and the quagga mussel (Dreissena bugensis), are well-known for their harm to native mussels and water quality and costly effects on infrastructure, fish hatcheries, navigational locks, and recreation. Zebra mussels are found in at least 30 U.S. States and in over 600 lakes and reservoirs, including the Great Lakes (Benson 2017). Zebra mussel populations can become so dense that they effectively smother aquatic plants and organisms on the bottom of lakes and encrust water intake pipes. This may significantly impact cooling systems of power plants, turbines used in hydropower generation, and water treatment facilities with costs of hundreds of millions of dollars across all sectors (Connelly et al. 2007; Strayer 2009).

In addition, aquatic invasive species can affect ambient water quality. Zebra mussels and other introduced invasive bivalves (e.g., the quagga mussel and Asiatic clam (Corbicula fluminea)) are highly productive filter feeders. When their 
populations are sufficiently large, they can significantly reduce the concentration of phytoplankton in the systems that they colonize. This may increase water clarity but can lead to a collapse in the pelagic community as seen in the Hudson River in 1991 (Strayer 2010). Selective filter feeding by zebra mussels has also promoted blooms of the toxinproducing cyanobacterium Microcystis aeruginosa, which can poison wildlife, domestic animals, and humans if ingested (Butler et al. 2009; Falconer 2005; Vanderploeg et al. 2001)

\subsubsection{Impacts of Invasive Species on Recreation and Public Safety}

Many invasive species, such as common reed or Japanese knotweed (Fallopia japonica), can impede water views and public access to recreational water bodies. Invaders can also pose public hazards associated with build-up of flammable biomass. Such species aggressively colonize shorelines of lakes, rivers, and coastal areas and require repeated and costly management efforts for their control. In some cases, the dense vegetation associated with invasive species can provide cover for illegal or illicit activities. Zebra mussels and introduced bivalves colonize lake and river bottoms. Their sharp shells can cut bare feet making water shoes a necessity and barefoot swimming a thing of the past.

Many States have implemented regulations that require cleaning the hulls of boats and other equipment to prevent the unintended spread of invasive plants and animals from lake to lake and river to river. For example, Minnesota, Missouri, Alaska, Vermont, and Maryland either prohibit or discourage anglers from wearing "porous soled" boots (often with felt bottoms) because these types of fishing boots can transport many invasive species: zebra mussel larvae, rock snot algae (Didymosphenia geminata), water fleas (Bythotrephes longimanus (cederstroemi), Cercopagis pengoi), viral hemorrhagic septicemia (Oncorhynchus 2 novirhabdovirus) which affects fish, whirling disease (Myxobolus cerebralis), faucet snails (Bithynia tentaculata), and New Zealand mud snails (Potamopyrgus antipodarum) (MN DNR 2017). Traditional cleaning methods (e.g., bleach) do not adequately kill the hitchhikers on these boots, therefore switching to alternative types of non-felt bottomed footwear is preferred. While necessary, such measures place an unwanted burden on recreational fishermen that may discourage their compliance.

Some non-native fishes are deliberately stocked with intent to provide recreational opportunities for anglers. For example, in the West, recreational fisheries have been stocked with smallmouth (Micropterus dolomieu) and largemouth bass (M. salmoides). There are recreational trophy fisheries for Atlantic salmon (Salmo salar) in Oregon, while fisheries for rainbow trout (Oncorhynchus mykiss) exist in many locations in Eastern North America. In 2015, the American Sportfishing Association estimated that freshwater sport fisheries support a \$115-billion annual industry (ASA 2015). When introduced non-native sport fish become invasive, the strong economic value of non-native sport fishes may complicate efforts to restore or protect native fishes (Cambray 2003). Some non-native sport fishes are strong predators and may dominate food sources or habitat thereby restructuring native ecosystems (Cambray 2003).

\subsubsection{Management Approaches for Water Resources and Systems}

It will continue to be a challenge to manage water resources colonized by invasive species, particularly with the emergence of climatic variability and change. Because invasive species interact with both the biotic and abiotic environment, detailed knowledge of the life history of invaders and information on the site being invaded is needed to maximize management efforts. In addition, the interaction of novel groupings of species and the advent of climate change are creating new ecosystems (Hobbs et al. 2009), often through destruction and re-structuring of existing native systems (Simberloff and Von Holle 1999). Consequently, it will be a challenge to develop effective strategies for managing water resources. Managers of aquatic systems are likely to encounter new invaders that require treatments (Strayer 2010) which may strain budgets. Long-term monitoring of invaded and restored sites, and real-time reporting of invasive species sightings in publicly available datasets, could facilitate detecting new introductions (or decreases in invader populations). Such information would assist managers in targeting high-priority areas for control, and potentially improve management efficiency by allowing managers to target more than one invasive species at a time (Catford 2017). Continued efforts by Federal, State, and local agencies; nongovernmental organizations; and other private entities to educate the public about the negative effects of invasive species on water resources, and to employ outreach efforts to engage the public, are critical in combatting and reporting aquatic invasive species. Additional details for early detection, management approaches, restoration, and rehabilitation for aquatic invasives and aquatic ecosystems are also discussed in Chaps. 6, 7 and 8.

\subsection{Invasive Species and Energy Systems}

Terrestrial and aquatic energy systems can be conduits for connectivity and dispersal of invasive species. Terrestrial energy systems are often extensions of urban ecosystems and 
connect rural areas through utility corridors. In aquatic systems, reservoirs or long slow-water river reaches associated with hydropower dams and energy generation often serve as prime habitat for invasive predatory warm-water fishes (that ultimately may have strong recreational value) and affect native fish survival and the trophic structure of river reaches. In both terrestrial and aquatic environments, invasive species can directly damage energy infrastructure, contribute to hazards that can damage infrastructure, and incur costs for removal.

\subsubsection{Impacts of Invasive Species and Energy Systems}

Several species have caused direct damage to electrical equipment. Invasive tawny crazy ants (Nylanderia fulva) infest electrical equipment and cause short circuits, equipment failures, and obstructions in switching mechanisms. It is estimated that tawny crazy ants cause $\$ 146.5$ million in damage to electrical equipment (ISAC 2016). The monk parakeet (Myiopsitta monachus), which is native to South America, causes short circuits and electrical fires because of its nesting behavior. The damages and power outages attributed to the stick-built nests lead to an increase in operation and maintenance costs (Booy et al. 2017). Brown tree snakes were accidentally introduced to the island of Guam after World War II. They cause power outages by actively crawling up utility poles, climbing power lines, and entering transformers. It is estimated that a single island-wide power outage caused by the snake can cost the power utility company more than $\$ 6$ million per year (Pimentel et al. 2005).

Invasive aquatic mollusks (i.e., zebra mussel, quagga mussel, Asian clam (Potamocorbula amurensis)) can cause significant expense if/when they contaminate hydropower facilities. Because these species deeply encrust exposed pipes, openings, or surfaces, they can clog water intakes and pipelines (Rosaen et al. 2012). These invasives can also infiltrate interior portions of power plants and dams, greatly affecting operations and increasing maintenance costs (ISAC 2016). The Anderson Economic Group cites mollusk infestation as the reason behind the closure of the Detroit Edison (later named DTE Energy) Power Generation Plant in Monroe, MI; customers were without power for 3 days (Park and Hushak 1999).

When invasive species damage or kill trees, these trees and associated limbs can pose a threat to utility lines and poles. Utility companies face increasing costs to maintain power lines in areas where trees are infested or diseased (Aukema et al. 2011). Power companies not only need to repair damaged wires and poles after treefall, but need to clear corridors of trees to prevent potential damage to lines. The highly invasive vine kudzu (Pueraria montana var. lobata) can smother poles and lines, increasing fire hazards and weighing down lines; it is estimated that kudzu costs power companies \$1.5 million per year (Blaustein 2001).

Occasionally, energy systems play a role in the conveyance of non-native species, for example, utility corridors may function as a focal point for invasion of adjacent natural ecosystems by non-native plant species (Zink et al. 1995). Activities associated with oil and gas development can facilitate the spread of invasive species through large-scale land clearing, movement of people and equipment, and transport of soil. Development activities promote the transfer of people and equipment from distant locations and thus facilitate the transport of invasive species to and from sites. Recently disturbed land lends itself to easy movement of invasive animals such as feral swine and rats (IOGP et al. 2010) and establishment of invasive plants that thrive in the disturbed soils and shade-free environment. Much like fire breaks, these corridors can promote the spread of invasive species into wildland areas (Keeley 2006).

In aquatic settings, hydropower dams used for energy generation cause significant changes to free-flowing rivers. Reservoirs created by dams and changes in river gradient due to altered flow patterns may alter thermal regimes and flow pathways (Poff et al. 1997). Additionally, reservoirs become important destinations for anglers, boaters, and others seeking recreation. Because boats are a primary vector in the unintentional introduction of aquatic invasive species, reservoirs may be among the initial areas contaminated in any particular region (Rothlisberger et al. 2010). Lastly, intentional introduction of invasive sport fishes may alter trophic systems and increase pressure on native fishes that are also contending with significant habitat changes associated with hydropower dams.

\subsubsection{Management Options for Energy Systems}

Management of invasive species that affect energy systems varies in terrestrial and aquatic ecosystems and includes a range of treatment options described in greater detail in Chap. 7. Invasive plants are often controlled in energy corridors through mowing regimes, removal of vines, and use of herbicides.

In areas impacted by zebra mussels, hydropower companies maintain water intakes by clearing mussels from intake pipes. Anti-fouling paint and hypochlorite systems can be used to inhibit further colonization. In the Great Lakes region, hydropower companies spend millions of dollars annually to mitigate the mussel problem and deliver lake 
water to power generation facilities (Rosaen et al. 2012). The Bonneville Power Administration estimated that it would cost approximately $\$ 1.8$ million to install hypochlorite systems and apply anti-fouling paint to 26 hydropower dams in Idaho to address the zebra mussel problem (Phillips et al. 2005).

There has been some discussion of using the harvested biomass of some of the established fast-growing invasive plant species as feedstock for biofuels (Jakubowski et al. 2010; Young et al. 2011). However, numerous challenges remain including the limited number of biorefineries; the costs of biomass harvest, transportation, and storage; environmental damage during harvest; and the potential to further spread invasive species during transport (Quinn et al. 2014).

\subsection{Invasive Species and Transportation Systems}

U.S. transportation systems include roads, railways, airways, and water transport. They not only crisscross the Nation but connect all private and public lands. As such, they can be important corridors of invasive species. Invasive species can impact transportation infrastructure, the safety of travelers, and property values. Costs associated with control of invasive species are extensive but are not fully tracked. For example, States do not itemize the cost to control invasive plants in roadside construction or maintenance.

This section covers road and rail transportation systems but does not cover air systems. Impacts associated with water transportation are addressed in Sects. 9.5 and 9.6.

\subsubsection{Road and Railways as Conduits of Invasive Species Spread}

Roadsides are prone to the invasion of non-native plant (Gelbard and Belnap 2003; Mortensen et al. 2009; Rentch et al. 2005) and animal (Hulme 2009; King et al. 2009) species as roads and road maintenance are vectors for their dispersion. For example, spread rates of Japanese stiltgrass (Microstegium vimineum) are notably higher along roads than in forests and wetlands (Mortensen et al. 2009). Fire ants have been spread over long distances and on different roads because the soil used for roadside fills came from the same ant-infested soil depot (King et al. 2009; Stiles and Jones 1998). Invasive cane toads (Rhinella marina) in Australia travel more quickly using roads than the adjacent vegetated sites (Brown et al. 2006), a particular concern as cane toads have also been introduced to Hawaii and the Caribbean. Several studies also show that the likelihood of an invasive plant being present in abundance increases significantly with proximity to a road (Flory and Clay 2009; Huebner and Tobin 2006). Roads provide a constant source of disturbance in the form of open, bare areas with high light levels that make them susceptible to rapid colonization by opportunistic species, including invasive species (Parendes and Jones 2000).

Invasions are particularly common in roads or railways that are paved, have a wide verge, or are in open areas as opposed to forested areas (Hanson and Clevenger 2005; Joly et al. 2011; Kalwij et al. 2008; Neher et al. 2013). Paved roads tend to have alkaline soils and are also characterized by higher metal concentrations, conditions that may be better tolerated by some invasive plants than native plants (Barbosa et al. 2010; Neher et al. 2013). Off-road vehicle trails are also an important conduit for invasive species into more remote forested sites (Rooney 2005). Some invasive plants, such as the common reed, can be found on older roadsides that have a history of exposure to de-icing salts, ditch digging, and nitrogen input from nearby agricultural fields (Jodoin et al. 2008). Invasive earthworms may also be found on older roads with reduced forest cover and on agricultural soils (Cameron and Bayne 2009; Hulme 2009).

During the process of road-building or upgrading a highway, top soils are scraped, stockpiled, and moved throughout the construction site. When the soils are moved, existing invasive seed and vegetative parts as well as invasive insects, earthworms, and pathogens may also move. Sand and gravel materials imported for building the road may also contain invasive species (Godefroid and Koedam 2004; Johnston and Johnston 2004). Top soils or mulch imported for special plantings may not be screened or treated before transport, and thus may harbor additional invasive propagules (Kruse et al. 2004).

In some areas, invasive species such as sweetclover (Melilotus officinalis), smooth brome (Bromus inermis), perennial rye (Lolium perenne), bird's-foot trefoil (Lotus corniculatus), crownvetch (Securigera varia), and reed canary grass (Phalaris arundinacea) have been purposefully introduced post-construction to control erosion because many native warm season or perennial plant species are slow to establish. However, some research indicates that highly effective seed mixes could be provided for these corridors if greater efforts were directed at selecting the right native seed mixes (Seastedt et al. 2008; Tinsley et al. 2006).

Vehicles can carry invasive seed and produce air turbulence that spreads seeds (Ansong and Pickering 2013; Taylor et al. 2012; Von der Lippe and Kowarik 2007). A review of 13 studies conducted across the globe involving seed dispersal associated with cars concluded that 626 species of seed were collected on vehicles (Ansong and Pickering 2013). 


\subsubsection{Impacts of Invasive Species on Roads and Railways}

Once established on roadsides, invasive plant species have been reported to reduce visibility and block roads and railways because of falling trees or accumulation of leaf litter. The United Kingdom has estimated such interference has cost at least $£ 30$ million ( $\$ 39$ million) annually (Williams et al. 2010). Existing or future colonization of non-native invasive plants can reduce the biodiversity of flora and the presence of associated butterflies and moths in roadside verges (Valtonen et al. 2006). Nutria (Myocastor coypus), a large invasive semi-aquatic rodent, can burrow into flood levees, undermining their structural integrity and leaving low-lying road and railways vulnerable to water damage (Leblanc 1994).

Invasive species can also enhance natural disturbances that can damage transportation infrastructure. For instance, cheatgrass increases the frequency of wildfires (Whisenant 1989), which may damage roads and railway systems by warping roadways and tracks, producing toxic gas, and destroying railway ties (Bonati et al. 2012; Rutz et al. 2014; Schartel et al. 2010).

\subsubsection{Management Options for Roads and Railways}

Management options are available to limit the introduction, establishment, and spread of invasive plant species along roadways. Within the National Highway System, each State is responsible after initial construction or upgrade for maintenance of all interstate, State, county, and local roads. States are eligible for Federal financing to prevent and control noxious weeds (invasive plants that cross the threshold of harm to agriculture, environment, or human health) on rights-ofway or roadsides; however, few States have fully used funding for weed control because State maintenance departments must compete against funding for pavement and bridges within their State's budgets.

Control of invasive plants prior to construction or upgrades can limit regrowth of invasive plants on the site later. Although the Federal Highway Administration recommends that all States inventory their roadside vegetation (including existing species, planted species, and invasive plants) and has developed a GPS-inventory protocol, few States keep good baseline records. As a result, States may not be aware of the presence of invasive plants at a given site or if their control efforts were successful on that site.

To limit the transfer of invasive weeds and seed, mulches applied for erosion control and sand and gravel pits used as sources for materials can be certified as weed-feed. In addition, roadside crews can use seed mixes for erosion control and roadside landscaping that are free of invasive species. The use of native grassland species requires less mowing and less use of chemicals to control weeds. Plantings of native grasses may actually limit the invasion of new invasive species (Pokorny et al. 2005; Sheley and James 2010). The Federal Highway Administration has also supported the development of a native erosion control sod to fulfill the needs of National Pollutant Discharge Elimination System erosion control permits.

Spread of invasive plants can be controlled after roadside maintenance. Portable washing machines are available so crews can wash equipment on site after mowing and construction operations and before equipment is moved offsite (Fleming 2008). If timed correctly, mowing can be an effective control method for some invasive plants. For example, if Japanese stiltgrass is mowed low right after it flowers in late August and early September, but before it fruits in late September or early October, this annual will fail to reproduce seed that year (Shelton 2012). Unfortunately, roadsides are often inhabited by a wide variety of species with different flowering and fruiting times. In addition, with many roads to mow, coordinating the timing of mowing may not be a realistic option. Attempts at reducing the spread of invasive species along roads are also most effective if all landowners along the corridor coordinate their efforts. However, this can be a challenge (Epanchin-Niell et al. 2010).

By spot spraying sites for invasive species rather than blanket spraying herbicides, or by using biocontrol alternatives, crews can limit disturbance that might allow for the colonization of invasive plants. Site disturbance can also be reduced by limiting grazing on difficult-to-access steep slopes and wetlands. The use of yearly prescribed fires on road shoulders may be effective to control invasive plants in some grassland areas with low traffic. By alternating herbicides, managers may limit increases in chemical resistance in weeds.

Knowledge of best management practices varies among States and even among State maintenance districts, and therefore training may be useful. Botanical expertise within State Departments of Transportation (DOT) can help states identify site-specific native seed mixes preferred for use in projects. Roadside managers with sufficient expertise and capacity can become frontline reporters of new invasive plants. In Minnesota, a DOT maintenance worker identified and reported oriental bittersweet (Celastrus orbiculatus) on a roadside, providing Minnesota DOT the opportunity to mobilize a response to limit its spread. GPS inventory methods for examining transportation corridors can help minimize the costs associated with the inventory of invasive species.

State partnerships with public and private lands across the right-of-way fence line can also be established to minimize invasions. For example, in 2009 the Minnesota DOT entered 
into a Memorandum of Understanding with the Fond du Lac Band of Lake Superior Chippewa in order to address concerns over use of herbicides and tree encroachment. Both parties agreed on the need to control invasive species.

\subsection{Invasive Species and Forest and Grassland Products}

As invasive species have become established in many U.S. forests and rangelands, they may interact with introduced livestock as well as the forest species we have come to rely on for timber and non-timber forest products. They can impact the health, productivity, and survival of these provisioning species and the management expenses associated with the production of food, feed, fuel, and fiber (DiTomaso 2000; French 2017; Kenis et al. 2017).

Invasive species are of great concern in most agricultural production; however, production systems such as croplands, orchards, and enclosed contained commercial animal operations are beyond the scope of this assessment. However, for cattle grazing on pastures or rangelands in Texas, the invasive cattle ticks, Rhipicephalus annulatus and $R$. microplus, carry the parasite Boophilus microplus, which causes tick fever (bovine babesiosis). Millions of dollars have been spent to keep the ticks from entering the United States from Mexico, and quarantine zones have been implemented along the border of Texas. In 2010, Texas A\&M University estimated the costs of treatment of cattle ticks at $\$ 122,983,110$ (Anderson et al. 2010). The ticks can also use native and imported ungulates as hosts, thus potentially spreading throughout native rangelands. White-tailed deer (Odocoileus virginianus) have been the most important alternative hosts. A January 2017 survey has shown the ticks are again advancing and extending their range throughout Texas (Texas Animal Health Commission 2017).

Invasive plant species can also decrease the quantity and quality of forage for livestock (DiTomaso 2000). Some have low palatability or may be poisonous, or may change soil or hydrologic regimes. Knapweeds and star-thistle (Centaurea spp.) and leafy spurge (Euphorbia esula) may reduce grazing capacity by as much as $50 \%$ (Olsen 1999). In California, the occurrence of yellow star-thistle on private land is estimated to cost cattle ranchers $\$ 7.65$ million dollars annually in lost forage (Eagle et al. 2007). Leafy spurge in Montana, North Dakota, South Dakota, and Wyoming has been estimated to decrease grazing capacity by approximately 90,000 cattle (Leistritz et al. 2004).

Alteration of fire regimes by invasive annual grasses such as cheatgrass, medusahead (Taeniatherum caput-medusae), and ventenata (Ventenata dubia) is a particular threat to western rangeland products. Invasion by grass species following fire can promote strong feedbacks, a process fre- quently referred to as the "grass-fire cycle" (Chap. 2, Box 2.1 , this volume). It is widely recognized that there is an emergent risk of rangeland degradation and reduction in forage because of invasive-dominated grasslands that burn readily (Chambers et al. 2014). New approaches, such as using late-season cattle grazing, are now being evaluated to reduce cheatgrass and other annual invasives (Schmelzer et al. 2014). Due to the poor forage quality, ranchers must provide protein supplements to cattle grazing on these grasses (Schmelzer et al. 2014).

Since invasive species can impact forest species composition and productivity, and the capacity of native species to regenerate after disturbance, they can impact the supply of both timber and non-timber forest products. Invasive invertebrates, pathogens, and plants have a direct impact on forest products in the United States, although there is limited information available on the extent of economic damages to the forest products industry (Kenis et al. 2017).

Emerald ash borer, which affects all species of ash trees in the Eastern United States (Herms and McCullough 2014), is estimated to cause $\$ 60$ million in timber value loss (Aukema et al. 2011). White ash is the most commercially important of the ash species; white ash logs are processed into diverse products including tool handles, baseball bats, railroad ties, flooring, cabinets, furniture, and cargo crates (MacFarlane and Meyer 2005). Additionally, mortality of black ash (Fraxinus nigra) has been of particular concern to Native Americans and other artisans who use black ash for basketmaking (Diamond and Emery 2011).

The ability of Asian longhorned beetle to attack multiple genera of apparently healthy hardwood trees is estimated to cause $\$ 41$ billion in potential losses to forest products, commercial fruit, maple syrup, nursery, and tourist industries (Fleming et al. 2002; Meng et al. 2015; USDA APHIS PPQ 2007). This woodborer is of great concern in North America because of the economic importance of maple (Acer spp.), one of its primary host genera. Maple is a prominent component of the northern hardwood forests that range from southeastern Canada to central New England west to the Great Lakes region, and is valued for its colorful fall foliage and maple syrup products (Dodds and Orwig 2011).

Gypsy moth larvae cause damage to broadleaved trees such as oak (Quercus spp.) and aspen (Populus spp.) by feeding on foliage. Defoliation has resulted in declines in the radial increment of oak trees (Muzika and Liebold 1999), and successive years of defoliation may cause extensive tree mortality. Aukema et al. (2011) estimate annual timber losses due to gyspy moth at $\$ 4.6$ million.

The walnut twig beetle, a species native to the Southwestern United States but invasive in the East, is vector to a fungus (Geosmithia mobida) that causes thousand cankers disease in walnut trees (Juglans spp.) (Utley et al. 2013). Black walnut (J. nigra) is prized for its resistance to decay, 
and its uses in wood products include furniture, specially items, gunstocks, and paneling (Voulgaridis and Vassiliou 2005). Black walnuts are valued as food and medicine, and are of commercial value. Hammons Products estimates that it harvests over 25 million pounds of black walnuts, mostly from wild trees (Chamberlain et al. 1998).

The invasive fungi Ceratocystis fimbriata and Fusarium oxysporum have been of particular concern in Hawaii. On the Big Island, $C$. fimbriata has damaged native 'ohi'a (Metrosideros polymorpha), which is not only a culturally important endemic tree, but also important for construction and specialty wood products, and whose flowers are used to make lei. Leaves of infected trees turn yellow and brown, and tree mortality may occur within a few weeks; $100 \%$ stand mortality can occur in 2-3 years (Friday et al. 2015). F. oxysporum has been responsible for wilt disease in koa trees (Acacia koa) (Gardner 1980), which has made regeneration of koa a challenge. Koa is one of Hawaii's largest native trees, valued for its wood, which is used to make furniture, veneer, and crafts (Skolmen 1974). The wood is one of the most expensive in the world, and due to its tonal properties is used to make instruments such as the ukulele and acoustic guitar (Shafto and McDaniel 2009); dyes are also made from its bark (Krauss 1974; Krohn-Ching 2016).

In some areas, invasive plants may outcompete native tree species, making it difficult or more costly for landowners to sustain healthy forests that ultimately can be harvested for forested products. Kudzu is a significant challenge for forest managers because it grows rapidly, and can wind itself around trees, shading native foliage and inhibiting photosynthesis (Forseth and Innis 2004). Affected trees may die within 2-3 years (Britton et al. 2002; Mitich 2000). Lost forest productivity due to kudzu is estimated at \$100-500 million per year (Forseth and Innis 2004). In Hawaii, invasive grass-fire complexes have replaced much native dry forest (Bruegmann 1996). These forests are a source of many forest products including those derived from koa and 'ōhi' a .

\subsubsection{Management Options to Limit Damage to Forest and Grassland Products}

Management options to limit the introduction, establishment, and spread of invasive species and to restore impacted ecosystems have been addressed in Chaps. 6, 7, and 8 and, consequently, are only briefly addressed in this section.

On rangelands, management of invasive plants can include a range of tactics including mechanical control, management of grazing, prescribed fire, revegetation programs, biological and chemical control, and integrated approaches (DiTomaso 2000). Mechanical control may include tilling, mowing, hand-pulling, and use of heavy machinery for inva- sive woody plants. Shifts in grazing strategies may be used to change the intensity and type of foraging and disturbance to soils (Olsen 1999). Prescribed fire can be effective but must be carefully timed prior to when seed production of invasive species occurs, in order to prevent their further spread. Timing of herbicide applications is also critical and may vary depending on the herbicide used (DiTomaso 2000).

For invasive insects such as emerald ash borer, goldspotted oak borer (Agrilus auroguttatus), and Asian longhorned beetle, significant effort has been placed on limiting transport of host material, including firewood, logs, and nursery stock (Haack 2006; Haack et al. 2010a; Koch et al. 2012a; Seybold et al. 2010). In 2009, USDA APHIS formed the National Firewood Task Force to develop a coordinated response to address outreach and voluntary and regulatory aspects of firewood movement at a national level (USDA APHIS PPQ 2010). Quarantines have been used to limit the spread of several invasive invertebrates. Several States have restricted the movement of walnut from counties with thousand cankers disease (USDA Forest Service et al. 2011). The Asian longhorned beetle has been under quarantine by State and Federal officials since its initial detection in the United States in 1996; eradication programs have been put in place in detected areas (Haack et al. 1997; Haack et al. 2010b; Lopez et al. 2017). Heating and fumigation may allow for the use and marketing of some infected wood (Audley et al. 2015; Wang 2012).

The spread of gypsy moths has been slowed by using pheromone traps to monitor low-level populations and then aerially applying pheromone flakes to disrupt mating (Sharov et al. 2002). To suppress or eradicate populations of gypsy moth, managers have often used aerial applications of Bacillus thuringiensis var. kurstaki, a bacterial pesticide (Kauffman et al. 2017). A naturally occurring nucleopolyhedrosis virus (NPV) is also being used in aerial and ground applications to suppress gypsy moth populations. The NPV product Gypchek was first registered as a general use pesticide with the U.S. Environmental Protection Agency in 1978 and, until recently, was produced through a contract with the USDA Forest Service (Reardon et al. 2012).

Research has also focused on developing more resilient forest stock. For example, efforts are underway to breed EAB-resistant ash. This work has involved examining the genome of Asian ash species that are less prone to infection, as well as the genome of isolated native ash populations which have survived in infected areas (Knight et al. 2012; Koch et al. 2012b; Whitehill et al. 2012). Scientists in Hawaii have worked to identify wilt-resistant koa seed for restoration and reforestation. With technical assistance from the USDA Forest Service, the Hawaii Agriculture Research Center has identified resistant parent trees, established seed orchards, and identified provisional seed zone guidelines (Dudley et al. 2017). 


\subsection{Invasive Species and Indigenous Peoples}

Native cultures and economies are grounded in land and natural resources (Pretty 2002). Any species that adversely impacts the water, land, plants, and animals on which indigenous peoples rely has negative consequences for these communities and cultures. Native peoples also have millennia of experience adapting to social and ecological change, which includes non-native species (Crosby 1986). Understanding indigenous experiences and traditional ecological knowledge is essential to developing invasive species management programs that honor the U.S. trust responsibility to Native peoples, and also is of benefit to others.

As of 2016, there were 566 federally recognized American Indian and Alaska Native tribes or communities in the United States, and an additional 60 tribes have been recognized through formal processes of U.S. State governments (National Conference of State Legislatures 2017). Tribes and Native communities hold over two million acres of land (National Congress of American Indians 2015) and have retained rights to hunt, fish, and gather on millions of additional acres. Treaty and case law require the Federal government to work with tribes and Native communities as sovereign nations for the protection of their lands and the resources on which they depend (National Congress of American Indians 2015). This doctrine extends to identifying, monitoring, and managing invasive species. Tribal cultural perspectives are covered extensively in Chap. 12.

\subsubsection{Impacts of Invasive Species on Indigenous Peoples}

Tribal natural resource professionals indicate that invasive species are having adverse impacts on the lands and communities they serve (for in-depth discussion see Chap. 12). Native perspectives on these species and what should be done about them are informed by recent and historical experience. In cases where recently arrived biota result in the rapid reorganization of landscapes, and/or replacement of culturally important species in two human generations or less, invasive species may be culturally impoverishing (Pfeiffer and Voeks 2008), with effects that include loss of access to cultural keystone species for food, medicinal, ceremonial, and other purposes (Garibaldi and Turner 2004) and interruptions of place-based traditions that literally ground indigenous identity (Pretty 2002). In other cases, invasives have enriched Native peoples' diets and pharmacopoeias, as exemplified by the weedy northern European species, English plantain (Plantago major L.) (Crosby 1986).
Indigenous communities are mindful of the social and political histories of many biological invasions. For example, the Dawes Act of 1887 resulted in privatization and ownership of land by non-Indians inside the boundaries of the Crow Indian Reservation, setting the stage for the contemporary invasion of Russian olive (Elaeagnus angustifolia L.) (Pretty Paint-Small 2013). Further, indigenous communities have suffered negative impacts from some programs designed to address invasive species, including use of toxic chemicals and biocontrol agents (Norgaard 2007; Pfeiffer and Voeks 2008).

The introduction of new species as a result of climate variability and change (see Chap. 4) increases demands on overcommitted Native and tribal natural resources departments, and creates both opportunities and challenges for collaboration with non-Native institutions. Each new invasive species identified will create a need for these staffs (with moderate resources) to work with community members, tribal government, and external land management agencies, in addition to their normal activities on the land. While there will be opportunities for tribes and Native communities to form learning partnerships with non-Native institutions, in the absence of established relationships of mutual respect and protocols for collaboration, the incidence of contested responses to invasive species may increase.

The incidence of rapid reorganization of landscapes, and replacement of culturally important native species, likely will increase with changing climate. As noted above, indigenous peoples have extensive experience adapting to new circumstances, but the pace of change can outstrip the capacity to adapt successfully, without significant cultural and economic disruption. In some cases, the consequence may be wide ranging for the health and well-being of Native and tribal communities, including loss of access to foods, medicines, crafts, and ceremonial materials, as well as the means for pursuing culturally appropriate sources of income.

\subsubsection{Management Options}

Future responses of indigenous communities to invasive species will reflect their cultures and economies. A non-native species is not necessarily regarded as undesirable to Native cultures. This judgment may hinge on whether a species is seen to compromise social, cultural, and economic wellbeing. For example, the Eastern Band of Cherokee Indians defines an invasive species as one that causes net harm to the tribe's economic or cultural resources. Where a species is determined to be harmful, some commonly used control and eradication methods may be unacceptable, and consequently indigenous communities may object to the invasive species management programs used or recommended by other land management agencies. One such case is the response of the 
Kashia Band of Pomo Indians to sudden oak death due to the pathogen Phytophthora ramorum. Although sudden oak death threatens a cultural keystone species (chishkale, or tanoak (Notholithocarpus densiflorus)), its primary inoculum source also is a culturally important species (pepperwood (Umbellularia californica)). Removal of pepperwood is one approach to managing sudden oak death. The Kashia decline to choose one culturally important tree species over another (Alexander et al. 2017).

Human health implications of pesticides and herbicides are paramount concerns for indigenous peoples, who may rely particularly heavily on food, medicine, and other materials harvested directly from the environment by community members. The Shoalwater Bay Tribe's experience with the tidal zone invasive plant spartina (Spartina alterniflora Loisel.) offers an example. Initially, the tribe declined to issue permits for herbicide applications to remove spartina on reservation land. When tribal members became increasingly aware of spartina's negative impacts on fishing and the State of Washington adopted an alternative chemical for its eradication, the Shoalwater Tribe partnered with the State's Spartina Technical Working Group. The tribe ultimately consented to targeted applications of the alternative herbicide on its lands, conducted by its own Natural Resources Department.

\subsection{Key Findings and Gaps in Information and Technology}

\subsubsection{Key Findings}

- Global travel and trade, international movement of livestock, translocation of wildlife and pets, modern agricultural practices, and changing climate patterns have led to the introduction of invasive vertebrate and invertebrate animals, plants, and microbial species, and the emergence of novel infectious diseases across North America and other continents.

- Expansion of the geographic range of invasive species and introduced diseases arises from changes in the interrelationships between the native host, invasive pathogen, and the local environment or ecosystem. Intervention in one or more of these parameters can disrupt or prevent the disease cycle.

- Invasive species pose numerous site-specific challenges to the U.S. military, many of which significantly impact mission critical activities. DoD implements a wide array of approaches to combat the spread of, and threats from, invasive species, often with the support of partners (public and private).

- Invasive species can damage infrastructure in urban and rural areas (e.g., buildings, utility lines, electrical sys- tems), and pose a risk to human health and safety. Invasive species may increase the risk of wildfire in the wildlandurban interface and number of hazardous trees in a community.

- Proper maintenance of urban plant communities at residential to city-wide scales may deter the spread of existing invaders. Creating green corridors can help reduce physical properties conducive to invasive species. Increasing the quantity of interconnected green infrastructure in urban areas may eventually make it easier to re-introduce native species.

- Invasive species can affect the amount of water available to communities, as well as the quality of untreated water. Control of invasive mussels is a serious maintenance problem for boat owners, and for power plants and other facilities that have water intake.

- Roads and railways are conduits for invasive species. Treatment of invaded areas, following nationwide policies, can help slow the spread of invasive species and limit invasion of nearby natural areas as well as rural communities.

- If not properly managed, invasive species can diminish the value of grazing lands, decrease the productivity of timberlands, and reduce production of non-timber forest products. Lost value and expenditures for management present major economic challenges for ranchers and forest managers.

- Invasive species have profound impacts on indigenous cultures and economies, compromising food supplies, traditional health systems, and spiritual practices at the heart of indigenous identity. Valuable insights for controlling invasive species may be acquired from Tribes' and Native communities' traditional ecological knowledge and land management practices (see Chap. 12).

- Better coordination of invasive species activities in all sectors of the United States may yield novel approaches, gains in efficiency, and increased capacity to respond to future invasions.

\subsubsection{Key Information and Technology Needs}

- Better understand the ecology, disease transmission, pathogenesis, and population biology of invasive species that impact human health, and the environmental variables that affect their distribution and spread.

- Develop new technologies and methods for early detection and monitoring of invasive insects and pathogens in forests, rangelands, urban areas, and transport systems, and enhance the availability of real-time data.

- Develop new technologies and methods for reducing the spread of invasive species and restoring native species along the urban-rural-natural area interface. 
- Identify the trade-offs associated with controlling invasive species (e.g., costs of control versus eradication, use of pesticides, damage to native species, and costs of not controlling the invasion).

- Better understand the interaction of climate change and invasive species, and associated sectoral impacts.

- Conduct research on genetic resilience to invasive pests and pathogens.

- Develop additional regional and species-specific information on the economic costs of invasive species (due to damage, management costs, and lost revenue) on infrastructure, military resources, forest and grassland products, urban vegetation, recreation, and tribal resources.

- Develop economic estimates of the costs of invasive species that factor in valuation of ecosystem services lost (e.g., pollination, soil carbon storage) with the decline or disappearance of native species.

- Identify how to best prioritize roads for treatment of invasive plants and restoration of native species.

- Develop a better understanding of gaps and barriers to interagency collaboration to prevent importation of highrisk animals into the United States, and to oversee imported animals.

- Better understand how economic incentives might be used to encourage planting of native species in urban environments with intent to limit the establishment and spread of invasive species.

- Identify the effects of indigenous land management practices on invasive species.

- Identify best practices for socio-cultural adaptation planning and management in order to address the impacts of invasive species in Native communities.

Acknowledgments The authors would like to thank those who provided input and reviewed this chapter. Special thanks to Derrick Golla, Valerie Leone, Kimberly Alles, and Booz Allen Hamilton for their document coordination and edits to the section on military readiness.

Disclaimer Text The findings and conclusions in this publication are those of the authors and should not be construed to represent any official USDA or U.S. Government determination or policy.

\section{Literature Cited}

Alexander JM, Frankel SJ, Hapner N et al (2017) Working across cultures to protect Native American natural and cultural resources from invasive species in California. J For 115:473-479

Alston KP, Richardson DM (2006) The roles of habitat features, disturbance, and distance from putative source populations in structuring alien plant invasions at the urban/wildland interface on the cape peninsula, South Africa. Biol Conserv 132:183-198

American Sportfishing Association (ASA) (2015) Economic contributions of recreational fishing: U.S. Congressional Districts. American Sportfishing Association. Southwick Associates. http://asafishing.
org/uploads/Congressional_District_Sportfishing_Impacts_2015_ Report.pdf

Anderson DP, Hagerman AD, Teel PD et al (2010) Economic impact of expanded fever tick range. Agricultural and Food Policy Center, Texas A\&M University System, College Station, 28 p

Ansong M, Pickering C (2013) Are weeds hitchhiking a ride on your car? A systematic review of seed dispersal on cars. PLoS One 8:e80275. https://doi.org/10.1371/journal.pone.0080275

Aronson MF, La Sorte FA, Nilon CH et al (2014) A global analysis of the impacts of urbanization on bird and plant diversity reveals key anthropogenic drivers. Proc R Soc B 281:20133330. https://doi. org/10.1098/rspb.2013.3330

Audley J, Taylor A, Klingman WE et al (2015) Insecticide dip treatments to prevent walnut twig beetle colonization of black walnut logs. For Prod J 66(34):235-240

Aukema JE, Leung B, Kovacs K et al (2011) Economic impacts of non-native forest insects in the continental United States. PLoS One 9:e24587

Ayron M, Bruland GL, MacKenzie RA, Giardina CP (2016) Soil and hydrological responses to wild pig (Sus scofa) exclusion from native and strawberry guava (Psidium cattleianum)-invaded tropical montane wet forests. Geoderma 279:53-60

Bagstad KJ, Wiederholt R (2013) Tourism values for Mexican freetailed bat viewing. Hum Dimens Wildl Int J 18:307-311

Balch JK, Bradley BA, D'Antonio CM, Gomez-Dans J (2013) Introduced annual grass increases regional fire activity across the arid western USA (1980-2009). Glob Chang Biol 19:173-183

Barberi MM, Kashinsky L, Littnan CL (2016) Protozoal-related mortalities in endangered Hawaiian monk seals (Neomonachus schauinslandi). Dis Aquat Org 121:85-95

Barbosa NPU, Fernandes GW, Carneiro MAA, Junior LAC (2010) Distribution of non-native invasive species and soil properties in proximity to paved roads and unpaved roads in a quartzitic mountainous grassland of southeastern Brazil (rupestrian fields). Biol Invasions 12:3745-3755

Beard CB, Eisen RJ (2016) Chapter 5 vector-borne diseases. In: The impacts of climate change on human health in the United States: a scientific assessment. U.S. Global Change Research Program, Washington, DC, pp 129-156

Bell GP (1997) Ecology and management of Arundo donax, and approaches to riparian habitat restoration in southern California. In: Brock JH, Wade M, Pyšek P, Green D (eds) Plant invasions. Studies from North America and Europe. Backhuys Publishers, Leiden, pp 103-113

Benson AJ (2017) The exotic Zebra Mussel. US Fish and Wildlife Service. https://www.fws.gov/midwest/endangered/clams/zebra. html

Bisognano JD, McGrody KS, Spence AM (2005) Myocarditis from the Chinese sumac tree. Ann Intern Med 143(2):159

Blaustein R (2001) Kudzu's invasion into southern United States life and culture. In: The great reschuffling: human dimensions of invasive species. IUCN, Gland, pp 55-62

Blosser EM, Burkett-Cadena ND (2017) Culex (Melanoconion) panocossa from peninsular Florida, USA. Acta Trop 157:59-63

Bonati A, Merusi F, Polacco G et al (2012) Ignitability and thermal stability of asphalt binders and mastics for flexible pavements in highway tunnels. Constr Build Mater 37:660-668

Booy O, Cornwell L, Parrott D et al (2017) Impact of biological invasions on infrastructure. In: Vilà M, Hulme PE (eds) Impact of biological invasions on ecosystem services. Springer International Publishing, Cham, pp 240-241

Botkin DB, Beveridge CE (1997) Cities as environments. Urban Ecosyst 1:3-19

Bower AD, St. Clair JB, Erickson V (2014) Generalized provisional seed zones for native plants. Ecol Appl 24:913-919 
Boyles JG, Cryan PM, McCracken GF, Kunz TH (2011) Economic importance of bats in agriculture. Science 332(6025):41-42

Britton KO, Orr D, Sun J (2002) Chapter 25, Kudzu. In: Van Driesche $\mathrm{R}$, Blossey B, Hoddle M et al (eds) Biological control of invasive plants in the eastern United States. USDA Forest Service Publication FHTET-2002-04, Morgantown

Brown GP, Phillips BL, Webb JK, Shine R (2006) Toad on the road: use of roads as dispersal corridors by cane toads (Bufo marinus) at an invasion front in tropical Australia. Biol Conserv 133:88-94

Bruegmann MM (1996) Hawaii's dry forests. Endanger Species Bull $11: 26-27$

Bureau of Planning and Sustainability (2016) Portland plant list. https:// www.portlandoregon.gov/citycode/article/322280

Butler N, Carlisle JC, Linville R, Washburn B (2009) Microcystins: a brief overview of their toxicity and effects, with special reference to fish, wildlife, and livestock. California Environmental Protection Agency, Office of Environmental Health Hazard Assessment, 17 p. https://oehha.ca.gov/media/downloads/ecotoxicology/document/ microcystin031209.pdf

California Department of Finance (2017) http://www.dof.ca.gov/ Forecasting/Demographics/Projections/

Cambray JA (2003) Impact on indigenous species biodiversity caused by the globalization of alien recreational freshwater fisheries. Hydrobiologia 500:217-230

Cameron EK, Bayne EM (2009) Road age and its importance in earthworm invasion of northern boreal forests. J Appl Ecol 46:28-36

Cannon WF, Horton JD (2009) Soil geochemical signature of urbanization and industrialization - Chicago, Illinois, USA. Appl Geochem 24:1590-1601

Catford JA (2017) Hydrological impacts of biological invasions. In: Vilà M, Hulme PE (eds) Impact of biological invasions on ecosystem services. Springer International Publishing, Switzerland, Cham, pp 63-80

Chamberlain J, Bush R, Hammett AL (1998) Non-timber forest products: the other forest products. For Prod J 48(10):10-19

Chambers JC, Bradley BA, Brown CS et al (2014) Resilience to stress and disturbance, and resistance to Bromus tectorum L. invasion in cold desert shrublands of western North America. Ecosystems 17:360-375

Clements S, Moore G (2003) Patterns of species richness in eight Northeastern United States cities. Urban Habitats 1(1): ISSN 15417115. Http://www.urbanhabitats.org

Coates PS, Ricca MA, Prochazka BG et al (2016) Wildfire, climate, and invasive grass interactions negatively impact an indicator species by reshaping sagebrush ecosystems. Proc Natl Acad Sci 113:12745-12750

Cohn JP (2005) Tiff over tamarisk: can a nuisance be nice, too? Bioscience 55:648-654

Collins MD, Vazquez DP, Sanders NJ (2002) Species area curves, homogenization and the loss of global diversity. Evol Ecol Res 4:457-464

Connelly NA, O’Neill CR Jr, Knuth BA, Brown TL (2007) Economic impacts of zebra mussels on drinking water treatment and electric power generation facilities. Environ Manag 40:105-112

Crosby AW (1986) Ecological imperialism: the biological expansion of Europe, 900-1900. Cambridge University Press, Cambridge

Dalsimer A (2002) Why DOD is interested in invasive species. Fed Facil Environ J 13:41-54

Darwin C (1859) The origin of species by means of natural selection. Murray, London

Daszak P, Cunningham AA, Hyatt AD (2000) Emerging infections diseases of wildlife - threats to biodiversity and human heath. Science 287:443-449

Dearborn DC, Kark S (2009) Motivations for conserving urban biodiversity. Conserv Biol 24(2):432-440
Defense Transportation Regulation (2018a) Department of Defense customs and border clearance policies and procedures. Chapter 505: agricultural cleaning and inspection requirements

Defense Transportation Regulation (2018b) Department of Defense customs and border clearance policies and procedures. Chapter 506 DoD Preclearance program customs and agriculture inspections

Department of Defense (DoD) (2011) Commander's guide on invasive species. http://www.dodnaturalresources.net/files/Commanders_ Guide_on_Invasive_Species_10.11.pdf

Department of Defense (DoD) (2017) Department of Defense: invasive species challenges and solutions. http://www.dodinvasives.org/ Invasives_and_Military_Feb2017.pdf

Department of Defense (DoD) (2018) Department of Defense Instruction Number 4715.03. Natural resource conservation program. https://www.esd.whs.mil/Portals/54/Documents/DD/issuances/dodi/471503p.pdf?ver=2018-11-13-125207-877

Department of Defense Armed Forces Pest Management Board (DoD AFPMB) (2016) DoD guidance for the surveillance, control and testing of Ae. aegytpti, Ae. albopictus and Ae. polynesiensis. http:// www.acq.osd.mil/eie/afpmb/docs/zika/Strategy_Control_Zika_ Virus.pdf

Department of Defense Armed Forces Pest Management Board (DoD AFPMB) (2017) Technical guide No. 31, guide for agricultural preparation of military gear and equipment for redeployment. https://www.acq.osd.mil/eie/afpmb/docs/techguides/tg31.pdf

Des Rosiers F, Theriault M, Kestens Y, Villeneuve P (2007) Landscaping attributes and property buyers' profiles: their joint effect on house prices. Hous Stud 22:945-964

Diamond AK, Emery MR (2011) Black ash (Fraxinus nigra Marsh.): local ecological knowledge of site characteristics and morphology associated with basket-grade specimens in New England (USA) 1. Econ Bot 65:422-426

DiTomaso JM (1998) Impact, biology, and ecology of Saltcedar (Tamarix spp.) in the Southwestern United States. Weed Technol $12: 326-336$

DiTomaso JM (2000) Invasive weeds in rangelands: species, impacts and management. Weed Sci 48:255-265

Dodds KJ, Orwig DA (2011) An invasive urban forest pest invades natural environments - Asian longhorned beetle in northeastern US hardwood forests. Can J For Res 41:1729-1742

Doherty TS, Glen AS, Dickman CR et al (2016) Invasive predators and global biodiversity loss. Proc Natl Acad Sci U S A 113:11261-11265

Donovan GH, Butry DT (2009) The value of shade: estimating the effect of urban trees on summertime electricity use. Energ Buildings 41:662-668

Doody BJ, Sullivan JJ, Meurk CD et al (2010) Urban realities: the contribution of residential gardens to the conservation of urban forest remnants. Biodivers Conserv 19:1385-1400

Drew J, Anderson N, Andow D (2010) Conundrums of a complex vector for invasive species control: a detailed examination of the horticultural industry. Biol Invasions 12:2837-2851

Dubey JP (2010) Toxoplasmosis of animals and humans, 2nd edn. CRC Press, Boca Raton, 313 p

Dubey JP, Jones JL (2008) Toxoplasma gondii infection in humans and animals in the United States. Int J Parasitol 38:1257-1278

Dudley N, Jones T, James R et al (2017) Applied genetic conservation of Hawaiian Acacia koa: an eco-regional approach. In: Sniezko RA, Man G, Hipkins V, Woeste K, Gwaze D, Kliejunas JT, McTeague BA, tech. cords (2017) Gene conservation of tree species-banking on the future. Proceedings of a workshop. General Technical Report PNW-GTR-963. U.S. Department of Agriculture, Forest Service, Pacific Northwest Research Station, Portland, OR, pp 78-91

Duguay S, Eigenbrod F, Fahrig L (2007) Effects of surrounding urbanization on non-native flora in small forest patches. Landsc Ecol 22:589-599 
Eagle AJ, Eiswerth ME, Johnson WS et al (2007) Costs and losses imposed on California ranchers by yellow star thistle. Rangel Ecol Manag 60:369-377

Ehrenfeld JG (2003) Effects of exotic plant invasions on soil nutrient cycling processes. Ecosystems 6:503-523

Elias SP, Lubelczyz CB, Rand PW et al (2006) Deer Browse resistant exotic-invasive understory: an indicator of elevated human risk of exposure to Ixodes scapularis (Acari: Ixodidae) in Southern Coastal Maine Woodlands. J Med Entomol 43:1142-1152

Epanchin-Niell RS, Hufford MB, Aslan CE et al (2010) Controlling invasive species in complex social landscapes. Front Ecol Environ $8: 210-216$

Ettestad P (2017) Overview of plague. Merck Manual, Veterinary Manual. In: http://www.merckvetmanual.com/ generalized-conditions/plague/overview-of-plague

Falconer IR (2005) Is there a human health hazard from microcystins in the drinking water supply? Acta Hydrochim Hydrobiol 33:64-71

Fall MW, Avery ML, Witmer G (2011) Chapter sixteen: rodents and other vertebrate invaders in the United States. In: Pimentel D (ed) Biological invasions: economic and environmental costs of alien plant, animal, and microbe species, 2nd edn. CRC Press, Boca Raton, pp 381-410

Fleming J (2008) Comparison of vehicle washing system. U.S. Forest service, prepared for Army Corps of Engineers and Engineer Research and Development Center. Strategic Environmental Research and Development Program Project SI-1545. http://www. dtic.mil/dtic/tr/fulltext/u2/a512807.pdf

Fleming MR, Hoover K, Janowiak JJ et al (2002) Microwave irradiation of wood packing material to destroy the Asian longhorned beetle. For Prod J 52(11/12):1-7

Flory SL, Clay K (2009) Effects of roads and forest successional age on experimental plant invasions. Biol Conserv 142:2531-2537

Forseth IN, Innis AF (2004) Kudzu (Pueraria montana): history, physiology, and ecology combine to make a major ecosystem threat. Crit Rev Plant Sci 23:401-413

French NP (2017) Impacts of non-native species on livestock In: Vilà M, Hulme PE (eds) Impact of biological invasions on ecosystem services. Springer International Publishing, Cham, pp 139-154

Friday J, Keith LM, Hughes F (2015) Ceratocystis Wilt of 'Ohi'a. Extension Publications. PD-107. College of Tropical Agriculture and Human Resources, University of Hawai' $i$ at Manoa

Gardner DE (1980) Acacia koa seedling wilt caused by Fusarium oxysporum. Phytopathology 70:594-597

Garibaldi A, Turner NJ (2004) Cultural keystone species: implications for ecological conservation and restoration. Ecol Soc 9(3):Art 1

Gelbard JL, Belnap J (2003) Roads as conduits for exotic plant invasions in a s semiarid landscape. Conserv Biol 17:420-432

Gill SE, Handley JF, Ennos AR, Pauleit S (2007) Adapting cities for climate change: the role of the green infrastructure. Built Environ 33:115-1333

Goddard MA, Dougill AJ, Benton TG (2009) Scaling up from gardens: biodiversity conservation in urban environments. Trends Ecol Evol 25:90-98

Godefroid S, Koedam N (2004) The impact of forest paths upon adjacent vegetation: effects of the path surfacing material on the species composition and soil compaction. Biol Conserv 119:405-419

Gomez-Aparicio L, Canham CD (2008a) Neighborhood analyses of the allelopathic effects of the invasive tree Ailanthus altissima in temperate forests. J Ecol 96:447-458

Gomez-Aparicio L, Canham CD (2008b) Neighborhood models of the effects of invasive tree species on ecosystem processes. Ecol Monogr 78:69-86

Grant EHC, Muths E, White CL et al (2016) Salamander chytrid fungus (Batrachochytrium salamandrivorans) in the United StatesDeveloping research, monitoring, and management strategies.
U.S. Geological Survey Open-File Report 2015-1233, 16 p. https:// doi.org/10.3133/ofr20151233

Griffin PM, Tauxe RV (1991) The epidemiology of infections caused by Escherichia coli $\mathrm{O} 157$ : H7, other enterohemorrhagic E. coli, and the associated Hemolytic Uremic Syndrome. Epidemiol Rev 13:60-98

Guo Q, Qian H, Ricklefs RE, Xi W (2006) Distributions of exotic plants in eastern Asia and North America. Ecol Lett 9:827-834

Haack RA (2006) Exotic bark- and wood-boring Coleoptera in the United States: recent establishments and interceptions. Can J For Res 36:269-288

Haack RA, Law KR, Mastro VC et al (1997) New York's battle with the Asian long-horned beetle. J For 95:11-15

Haack RA, Petrice TR, Wiedenhoeft AC (2010a) Incidence of bark-and wood-boring insects in firewood: a survey at Michigan's Mackinac bridge. J Econ Entomol 103:1682-1692

Haack RA, Hérard F, Sun J, Turgeon JJ (2010b) Managing invasive populations of Asian longhorned beetle and citrus longhorned beetle: a worldwide perspective. Annu Rev Entomol 55:521-546

Hancock DD, Besser TE, Kinsel ML et al (1994) The prevalence of Escherichia coli O157.H7 in dairy and beef cattle in Washington State. Epidemiol Infect 113:199-207

Hansen MJ, Clevenger AP (2005) The influence of disturbance and habitat on the presence of non-native plant species along transport corridors. Biol Conserv 125:249-259

Harris E, Ames JA, Packham AE, Conrad PA (2002) Coastal freshwater runoff is a risk factor for Toxoplasma gondii infection of southern sea otters (Enhydra lutris nereis). Int J Parasitol 32:997-1006

Havens K, Vitt P, Kramer AT et al (2015) Seed sourcing for restoration in an era of climate change. Nat Areas J 35:122-133

Hawaii Department of Agriculture (HDOA) (2016) Coconut Rhinoceros Beetle Program annual report/Farm Bill Survey - July 1, 2015 June 30, 2016

Hayes EB, Komar N, Nasci RS et al (2005) Epidemiology and transmission dynamics of West Nile Virus disease. Emerg Infect Dis 11:1167-1173

Herms DA, McCullough DG (2014) Emerald ash borer invasion of North America: history, biology, ecology, impacts, and management. Annu Rev Entomol 59:13-30

Hobbs RJ, Higgs E, Harris JA (2009) Novel ecosystems: implications for conservation and restoration. Trends Ecol Evol 24:599-605

Huebner CD, Tobin PC (2006) Invasibility of mature and 15-year-old deciduous forests by exotic plants. Plant Ecol 186:57-68

Huebner CD, Gottschalk KW, Miller GW, Brose PH (2010) Restoration of three forest herbs in the Liliaceae family by manipulating deer herbivory and overstorey and understorey vegetation. Plant Ecolog Divers 3:259-272

Hulme PE (2009) Trade, transport and trouble: managing invasive species pathways in an era of globalization. J Appl Ecol 46:10-18

Ignatieva M, Stewart GH, Meurk C (2011) Planning and design of ecological networks in urban areas. Landsc Ecol 7:17-25

International Association of Oil and Gas Producers (IOGP), International Petroleum Industry Environmental Conservation Association (IPIECA), Little D (2010) Alien invasive species and the oil and gas industry. IOGP Report Number 436. http://www.ipieca.org/resources/ good-practice/alien-invasive-species-and-the-oil-and-gas-industry/

Invasive Species Advisory Committee (ISAC) (2016) White paper: invasive species impacts on infrastructure. U.S. Department of the Interior, Washington, DC

Iverson M (1998) Effects of Arundo donax on water resources. CalEPPC News. California Exotic Pest Plant Council, Trabuco Canyon, p 10

Jakubowski AR, Casler MD, Jackson RD (2010) The benefits of harvesting wetland invaders for cellulosic biofuel: an ecosystem services perspective. Restor Ecol 18:789-795

Jay MT, Cooley M, Mandrell RE et al (2007) Escherchia coli O157:H7 in feral swine near spinach fields and cattle in Central California coast. Emerg Infect Dis 13:1908-1911 
Jessup DA (2004) The welfare of feral cats and wildlife. J Am Vet Med Assoc 225:1377-1383

Jodoin YD, Lovoie P, Villeneuve M et al (2008) Highways as corridors and habitats for the invasive common reed Phragmites australis in Quebec, Canada. J Appl Ecol 45:459-466

Johnston FM, Johnston SW (2004) Impacts of road disturbance on soil properties and on exotic plant occurrence in subalpine areas of the Australian Alps. Arct Antarct Alp Res 36:201-207

Joly M, Bertrand P, Gbangou RY et al (2011) Paving the way for invasive species: road type and the spread of common ragweed (Ambrosia artemisiifolia). Environ Manag 48:514-522

Jones JG, Russell DG (1968) Giant hogweed dermatis. Practitioner 200(1199):704-706

Kalwij JM, Milton SJ, McGeoch MA (2008) Road verges as invasion corridors? A spatial hierarchical test in an arid ecosystem. Landsc Ecol 23:439-451

Karnosky D (1979) Dutch elm disease: a review of the history, environmental implications, control, and research needs. Environ Conserv 6:311-322

Kauffman MD, LeJeune J (2011) European starlings (Sturnus vulgaris) challenged with Escherichia coli $\mathrm{O} 157$ can carry and transmit the human pathogen to cattle. Lett Appl Microbiol 53:596-601

Kauffman BW, Clatterbuck WK, Liebhold AM, Coyle DR (2017) Gypsy moth in the southeastern U.S.: biology, ecology, and forest management strategies. SREF-FH-008. Southern Regional Extension Forestry, Athens, $10 \mathrm{p}$

Keeley JE (2006) Fire management impacts on invasive plants in the western United States. Conserv Biol 20:375-384

Kenis M, Roques A, Santini A, Liebhold AM (2017) Impact of nonnative invertebrates and pathogens on market forest tree resources. In: Vilà M, Hulme PE (eds) Impact of biological invasions on ecosystem services. Springer International Publishing, Cham, pp 103-117

Kerns BK, Naylor BJ, Buonopane M et al (2009) Modeling tamarisk (Tamarix spp.) habitat and climate change effects in the northwestern United States. Invasive Plant Sci Manag 2:200-215

Kettenring KM, Adams CR (2011) Lessons learned from invasive plant control experiments: a systematic review and meta-analysis. J Appl Ecol 48:970-979

King JR, Tschinkel WR, Ross KG (2009) A case study of human exacerbation of the invasive species problem: transport and establishment of polygyne fire ants in Tallahassee, Florida, USA. Biol Invasions 11:373-377

Knight KS, Herms D, Plumb R et al (2012) Dynamics of surviving ash (Fraxinus spp.) populations in areas long infested by emerald ash borer (Agrilus planipennis). In: Sniezko RA, Yanchuk AD, Kliejunas JT, Palmieri KM, Alexander JM, Frankel SJ tech. coords (2012) Proceedings of the fourth international workshop on the genetics of host-parasite interactions in forestry: Disease and insect resistance in forest trees. General Technical Report PSW-GTR-240. Pacific Southwest Research Station, Forest Service, U.S. Department of Agriculture, Albany, CA, pp 143-152

Knowler D, Barbier E (2005) Importing exotic plants and the risk of invasion: are market-based instruments adequate? Ecol Econ 52:341-354

Koch FH, Yemshanov D, Magarey RD, Smith WD (2012a) Dispersal of invasive forest insects via recreational firewood: a quantitative analysis. J Econ Entomol 105:438-450

Koch JL, Carey DW, Knight KS et al (2012b) Breeding strategies for the development of emerald ash borer-resistant North American ash. In: Sniezko RA, Yanchuk AD, Kliejunas JT, Palmieri KM, Alexander JM, Frankel SJ (eds) Proceedings of the 4th international workshop on the genetics of host-parasite interactions in forestry: disease and insect resistance in forest trees. USDA Forest Service, Pacific Southwest Research Station, Albany, pp 235-239

Kolby JE, Daszak P (2016) The emerging amphibian fungal disease, chytridiomycosis: a key example of the global phenomenon of wildlife emerging infectious diseases. Microbiol Spectr 4(3):EI100004-2015. https://doi.org/10.1128/microbiolspec.EI10-0004-2015

Kovacs KF, Haight RG, McCullough DG et al (2010) Cost of potential emerald ash borer damage in US communities, 2009-2019. Ecol Econ 69:569-578

Kowarkik I (2011) Novel urban ecosystems, biodiversity, and conservation. Environ Pollut 159:1974-1983

Krauss BH (1974) Ethnobotany of Hawaii. Department of Botany, University of Hawaii, Honolulu, pp 127-130

Krohn-Ching VF (2016) Hawaii dye plants and dye recipes. University of Hawaii Press, Honolulu, 136p

Kruse R, Bend E, Bierzychudek P (2004) Native plant regeneration and introduction of non-natives following post-fire rehabilitation with straw mulch and barley seeding. For Ecol Manag 196:299-310

Lambrinos JG (2000) The impact of invasive alien grass Cortaderia jubata (Lemoine) Stapf. On an endangered Mediterranean-type shrubland in California. Divers Distrib 6:217-231

Lanier GN (1989) Trap trees for control of Dutch elm disease. J Arboric 15:105-111

Lax AR, Osbrink WL (2003) United States Department of AgricultureAgriculture Research Service research on targeted management of the Formosan subterranean termite Coptotermes formosanus Shiraki (Isoptera: Rhinotermitidae). Pest Manag Sci 59:788-800

LeBlanc DJ (1994) Nutria. In: Hygnstrom SE, Timm RM, Larson GE (eds) Prevention and control of wildlife damage. University of Nebraska, Lincoln

Leishman MR, Thomson VP (2005) Experimental evidence for the effects of additional water, nutrients and physical disturbance on invasive plants in low fertility Hawkesbury sandstone soils, Sydney. Aust J Ecol 93:38-49

Leistritz FL, Bangsund DA, Hodur NM (2004) Assessing the economic impact of invasive weeds: the case of leafy spurge (Euphorbia esula). Weed Technol 18:1392-1395

Liebhold A, Brokerhoff EG, Garrett LJ et al (2012) Live plant imports: the major pathway for forest insect and pathogen invasions of the US. Front Ecol Environ 10(3):135-143

Lopez VM, Hoddle MS, Francese JA et al (2017) Assessing flight potential of the invasive Asian longhorned beetle (Coleoptera: Cerambycidae) with computerized flight mills. J Econ Entomol 110:1070-1077

López-Hoffman L, Wiederholt R, Semmens D et al (2014) Market forces and technological substitutes cause fluctuations in the value of bat-control services for cotton. PLoS One 9(2):e87912

Lososova Z, Chyrtry M, Tichy L et al (2012) Biotic homogenization of Central Europe urban floras depends on residence time of alien species and habitat type. Biol Conserv 145:179-184

MacFarlane DW, Meyer SP (2005) Characteristics and distribution of potential ash tree hosts for emerald ash borer. For Ecol Manag 213:15-24

Mack MC, D'Antonio CM (1998) Impacts of biological invasions on disturbance regimes. Trends Ecol Evol 13:195-198

Maher SP, Kramer AM, Drake JM et al (2012) Spread of white-nose syndrome on a network regulated by geography and climate. Nat Commun 3:1306

Martel A, Spitzen-van der Sluijsb A, Pasmans F et al (2013) Batrachochytrium salamandrivorans sp. nov. causes lethal chytridiomycosis in amphibians. PNAS 110:15325-15329

Martin L, Blossey B (2013) The runaway weed: costs and failures of Phragmites australis management in the USA. Estuar Coasts 36:626-632

McDonald RI, Kareiva P, Forman RIT (2008) The implications of current and future urbanization for global protected areas and biodiversity conservation. Biol Conserv 141:1695-1703

McKinney ML, Lockwood JL (1999) Biotic homogenization: a few winners replacing many losers in the next mass extinction. Trends Ecol Evol 14:450-453 
Meng XJ, Lindsay DS, Sriranganthan N (2009) Wild boars as sources for infectious diseases in livestock and humans. Philos Trans R Soc 364:2697-2707

Meng PS, Hoover K, Keena MA (2015) Asian longhorned beetle (Coleoptera: Cerambycidae), an introduced pest of maple and other hardwood trees in North America and Europe. J Integr Pest Manag 6(1):4. https://doi.org/10.1093/jipm/pmv003

Meyerson LA, Saltonstall K, Windham L et al (2000) A comparison of Phragmites australis in freshwater and brackish marsh environments in North America. Wetl Ecol Manag 8:89-103

Meyerson LA, Cronin JT, Pyšek P (2016) Phragmites as a model organism for plant invasions. Biol Invasions 18:2421-2431

Miller MA, Miller WA, Conrad PA et al (2008) Type X Toxoplasma gondii in a wild mussel and terrestrial carnivores from coastal California: new linkages between terrestrial mammals, runoff and toxoplasmosis of sea otters. Int J Parasitol 38:1319-1328

Miller RS, Sweeney SJ, Slootmaker C et al (2017) Cross-species transmission potential between wild pigs, livestock, poultry, wildlife, and humans: implications for disease risk management in North America. Sci Rep 7:1-14

Minnesota Department of Natural Resources (MN DNR) (2017) Flyanglers and wader users: felt-soled wader issues and alternatives. http://www.dnr.state.mn.us/invasives/felt.html

Mitich LW (2000) Intriguing world of weeds. Kudzu Pueraria lobata (Willd.) Ohwi. Weed Technol 14:231-235

Mortensen DA, Rauschert ESJ, Nord AN, Jones BP (2009) Forest roads facilitate the spread of invasive plants. Invasive Plant Sci Manag 2:191-199

Murrell CE, Gerber C, Krebs M et al (2011) Invasive knotweed affects native plants through allelopathy. Am J Bot 98:38-43

Muzika RM, Liebhold AM (1999) Changes in radial increment of host and nonhost tree species with gypsy moth defoliation. Can J For Res 29:1365-1373

National Conference of State Legislatures (2017) Federal and state recognized tribes. National Conference of State Legislatures. http:// www.ncsl.org/research/state-tribal-institute/list-of-federal-andstate-recognized-tribes.aspx\#State

National Congress of American Indians (2015) An introduction to Indian Nations in the United States. http://www.ncai.org/ resources/ncai_publications/tribal-nations-and-the-united-statesan-introduction

NatureServe (2015) Species at-risk on Department of Defense Lands: 2014 updated analysis, report, and maps. http://www.natureserve. org/conservation-tools/projects/species-risk-dod-installations

Neher DA, Asmussen D, Lovell ST (2013) Roads in northern hardwood forests affect adjacent plant communities and soil chemistry in proportion to the maintained roadside area. Sci Total Environ 449:320-327

No, E.O. (2016) No. Executive Order. 13751. Safeguarding the nation from the impacts of invasive species. Federal Register 81: $88609-88614$

Norgaard KM (2007) The politics of invasive weed management: gender, race, and risk perception in rural California. Rural Sociol $72: 450-477$

Nowak DJ (2010) Urban biodiversity and climate change. In: Muller N, Werner P, Kelcey JG (eds) Urban biodiversity and design. WileyBlackwell Publishing, Hoboken, pp 101-117

Nowak DJ, Crane DE, Dwyer JF (2002) Compensatory values of urban trees in the U.S. J Arboric 28:194-199

Oke TR (1995) The heat island of the urban boundary layer: characteristics, causes, and effects. In: Cermak JE et al (eds) Wind climate in cities. Kluwer Academic Publishers, Amsterdam, pp 81-107

Olden JD, Rooney TP (2006) On defining and quantifying biotic homogenization. Glob Ecol Biogeogr 15:113-120
Olsen BE (1999) Grazing and weeds. In: Shely RL, Petroff JK (eds) Biology and management of noxious weeds. Oregon State University Press, Corvalis, pp 85-96

Olsen CW (2002) The emergence of novel swine influenza viruses in North America. Virus Res 85:199-210

Parendes LA, Jones JA (2000) Role of light availability and dispersal in exotic plant invasion along roads and streams in the H.J. Andrews Experimental Forest, Oregon. Conserv Biol 14:64-75

Park J, Hushak LJ (1999) Zebra mussel control costs in surface water using facilities. Technical summary Ohio State University, OHSU-TS-028. Ohio Sea Grant College Program, The Ohio State University, Columbus

Pederson K, Bevins SN, Schmidt BS et al (2012) Apparent prevalence of swine brucellosis in feral swine in the United States. Hum-Wildl Interact 6:38-47

Pejchar L, Mooney HA (2009) Invasive species, ecosystem services and human well-being. Trends Ecol Evol 24:497-504

Perry R (2013) White-nose syndrome in bats: an overview of current knowledge for land managers. . General technical report SRSGTR-184. U.S. Department of Agriculture Forest Service, Southern Research Station, Asheville, $9 \mathrm{p}$

Pfeiffer JM, Voeks RA (2008) Biological invasions and biocultural diversity: linking ecological and cultural systems. Environ Conserv 35:281-293

Phillips S, Darland T, Systma M (2005) Potential economic impacts of Zebra mussels on the hydropower facilities in the Columbia River basin. Pacific States Marine Fisheries Commission, Portland. http:// www.aquaticnuisance.org/wordpress/wp-content/uploads/2009/01/ Phillips-Darland-and-Sytsma.pdf

Pickett STA, Cadenasso MI, Grove JM et al (2001) Urban ecological systems: linking terrestrial ecological, physical and socioeconomic components of metropolitan areas. Annu Rev Ecol Syst 32:127-157

Pimentel D (2011) Environmental and economic costs associated with alien invasive species in the United States. In: Pimentel D (ed) Biological invasions: economic and environmental costs of alien plant, animal, and microbe species. CRC Press, Boca Raton, pp 411-430

Pimentel D, Lach L, Zuniga R, Morrison D (2000) Environmental and economic costs of nonindigenous species in the United States. Bioscience 50:53-65

Pimentel D, Zuniga R, Morrison D (2005) Updates on the environmental and economics costs associated with alien-invasive species in the United States. Environ Econ 52:273-288

Pines IL (2009) Forest pests in Manitoba 2008: Dutch elm disease management program in Manitoba. Proceedings of the forest pest management forum, 2-4 December, 2008, Gatineau, PQ (pp 88-94). Natural Resources Canada, Ottawa, ON. http://www.glfc.forestry. ca/VLF/ForumPresentations/pinesmanitoba_08e.pdf

Poff NL, Allan JD, Bain MB et al (1997) The natural flow regime. Bioscience 47:769-784

Pokorny ML, Sheley RL, Zabinski CA et al (2005) Plant functional group diversity as a mechanism for invasion resistance. Restor Ecol 13:448-459

Potts SG, Biesmeijer JC, Kremen C et al (2010) Global pollinator declines: trends, impacts and drivers. Trends Ecol Evol $25: 345-353$

Pretty J (2002) Landscapes lost and found. In: Pretty J (ed) Agriculture: reconnecting people, land and nature. Earthscan Publishing, London, pp 10-26

Pretty Paint-Small V (2013) Linking culture, ecology, and policy: the invasion of Russian Olive (Elaeagnus angustifolia L.) on the Crow Indian Reservation, South-Central Montana, USA. Doctoral dissertation, Bioagricultural Sciences and Pest Management, Colorado State University, Fort Collins, Colorado 
Quinn LD, Endres AB, Voigt TB (2014) Why not harvest existing invaders for bioethanol? Biol Invasions 16:1559. https://doi.org/10.1007/ s10530-013-0591-Z

Reardon R, Podgwaite J, Zerillo R (2012) Gypchek-environmentally safe viral insecticide for gypsy moth control. FHTET-2012-01. U.S. Department of Agriculture, Forest Service, Forest Health Technology Enterprise Team, Morgantown, $49 \mathrm{p}$

Reeder DM, Frank CL, Turner GG et al (2012) Frequent arousal from hibernation linked to severity of infection and mortality in bats with white-nose syndrome. PLoS One 7(6):e38920

Rentch JS, Fortney RH, Stephenson SL et al (2005) Vegetation-site relationships of roadside plant communities in West Virginia, USA. J Appl Ecol 42:129-138

Ricotta C, La Sorte FA, Pysek P et al (2009) Pyloecology of urban alien floras. J Ecol 97:1243-1251

Rooney TP (2005) Distribution of ecologically-invasive plants along off-road vehicle trails in the Chequmegon National Forest, Wisconsin. Mich Bot 44:178-182

Rosaen AL, Grover EA, Spencer CW, Anderson PL (2012) The costs of aquatic invasive species to the Great Lakes States. Anderson Economic Group

Rothlisberger JD, Chadderton WL, McNulty J, Lodge DM (2010) Aquatic invasive species transport via trailered boats: what is being moved, who is moving it, and what can be done. Fisheries 35:121-132

Roy S, Byrne J, Pickering C (2012) A systematic quantitative review of urban tree benefits, costs, and assessment methods across cities in different climatic zones. Urban For Urban Green 11:351-363

Rutz FR, Riley TM, Foster P (2014) Fire and reconstruction at Lobato bridge in New Mexico. J Preserv Technol 45:37-42

Sanders H, Polaska S, Haight RG (2010) The value of urban tree cover: a hedonic property price model in Ramsey and Dakota counties, Minnesota, USA. Ecol Econ 69:1646-1656

Schartel B, Bahr H, Braun U, Recknagel C (2010) Fire risks of burning asphalt. Fire Mater 34:333-340

Schmelzer L, Perryman B, Bruce B et al (2014) Case study: reducing cheatgrass (Bromus tectorum L.) fuel loads using fall cattle grazing. Prof Anim Sci 30:270-278

Schwartz MW, Thorne JH, Viers JH (2006) Biotic homogenization of the California flora in urban and urbanizing regions. Biol Conserv 127:282-291

Seastedt TR, Hobbs RJ, Suding KN (2008) Management of novel ecosystems: are novel approaches required? Front Ecol Environ 6:547-553

Seybold SJ, Coleman TW, Flint ML (2010) Burn it, chip it, or tarp it, but just don't move it: managing oak firewood infested with the goldspotted oak borer, Agrilus coxalis auroguttatus. In Sudden Oak Death Fourth Science Symposium, p 365

Shafto TD, McDaniel L (2009) Contemporary Hawai'i woodworkers: the wood, the art, the aloha. Contemporatry Publications, Mountain View, 223p

Sharov AA, Leonard DS, Liebhold AM et al (2002) Slow the spread: a national program to contain the gypsy moth. J For 100:30-35

Sheley RL, James J (2010) Resistance of native plant functional groups to invasion by medusahead. Invasive Plant Sci Manag 3:294-300

Shelton AL (2012) Mowing any time after midsummer can manage Japanese stiltgrass. Invasive Plant Sci Manag 5:209-216

Simberloff D, Von Holle B (1999) Positive interactions of nonindigenous species: invasional meltdown? Biol Invasions 1:21-32

Skolmen RG (1974) Some woods of Hawaii, properties and uses of 16 commercial species. USDA Forest Service general technical report PSW-8. PSW Forest and Range Experimental Station, Berkeley, p 30

Smith RM, Thompson K, Hodgson JG et al (2006) Urban domestic gardens (IX): composition and richness of the vascular plant flora, and implications for native biodiversity. Biol Conserv $129: 312-322$
Stiles JH, Jones RH (1998) Distribution of the red imported fire ant, Solenopsis invicta, in road and powerline habitats. Landsc Ecol 335:335-346

Stinson KA, Campbell SA, Powell JR et al (2006) Invasive plant suppresses the growth of native tree seedlings by disrupting belowground mutualisms. PLoS Biol 4(5):e104

Stout J, Morales CL (2009) Ecological impacts of invasive alien species on bees. Apidologie 40:388-409

Strayer D (2009) Twenty years of zebra mussels: lessons from the mollusk that made headlines. Front Ecol Environ 7:135-141

Strayer D (2010) Alien species in fresh waters: ecological effects, interactions with other stressors, and prospects for the future. Freshw Biol 55:152-174

Su N, Scheffrahan RH (2016) Formosan subterranean termite. Featured Creatures, University of Florida Institute of Food and Agricultural Sciences. Publication Number: EENY-121. http://entnemdept.ufl. edu/creatures/urban/termites/formosan_termite.htm

Sustainable Fort Bragg (2017) Burning towards success

Taylor K, Brummer T, Taper ML et al (2012) Human-mediated longdistance dispersal: an empirical evaluation of seed dispersal by vehicles. Divers Distrib 18:942-951

Texas Animal Health Commission (2017) Fever tick situation report of January 30, 2017. Fact sheet. Texas

Timm RM (1994) Norway rats. The handbook: prevention and control of wildlife damage. 5. http://digitalcommons.unl.edu/ icwdmhandbook $/ 5$

Tinsley MJ, Simmons MT, Windhager S (2006) The establishment success of native versus non-native herbaceous seed mixes on a revegetated roadside in Central Texas. Ecol Eng 26:231-240

Traveset A, Richardson DM (2006) Biological invasions as disruptors of plant reproductive mutualisms. Trends Ecol Evol 21:208-216

Turner GG, Reeder DM, Coleman JTH (2011) A five-year assessment of mortality and geographic spread of White-nose Syndrome in North American bats and a look to the future. Bat Res News 52:13-27

U.S. Deparatment of Agriculture, National Agricultural Statistics Service (2014) Census of agriculture, 2014 census of horticultural specialties. https://www.nass.usda.gov/Publications/AgCensus/2012/ Online_Resources/Census_of_Horticulture_Specialties/

U.S. Department of Agriculture, Animal and Plant Health Inspection Service (USDA APHIS) (2016) Feral Swine - risks to people and domestic animals. https://www.aphis.usda.gov/aphis/ourfocus/wildlifedamage/operational-activities/feral-swine/feral-swine-damage/ feral-swine-risks-pets-people

U.S. Department of Agriculture, Animal and Plant Health Inspection Service (USDA APHIS) (2017) August is tree check month: public's help needed to stop the invasive Asian Longhorned Beetle in its tracks. https://www.aphis.usda.gov/aphis/newsroom/news/ sa_by_date/sa-2017/alb-tree-check-month

U.S. Department of Agriculture, Animal and Plant Health Inspection Service (USDA APHIS) (2020). Emerald Ash Borer. https:// www.aphis.usda.gov/aphis/ourfocus/planthealth/plant-pestand-disease-programs/pests-and-diseases/emerald-ash-borer

U.S. Department of Agriculture, Animal and Plant Health Inspection Service, Plant Protection and Quarantine (USDA APHIS PPQ) (2007) Asian Longhorned Beetle: questions and answers

U.S. Department of Agriculture Animal and Plant Health Inspection Service, Plant Protection and Quarantine (USDA APHIS PPQ) (2010) National Firewood Task Force recommendations, USDAAPHIS-PPQ Fact Sheet. https://www.aphis.usda.gov/aphis/ ourfocus/planthealth/import-information/firewood

U.S. Department of Agriculture, Forest Service, Animal and Plant Health Inspection Service, National Association of State Foresters, National Plant Board (2011) National response framework for Thousand Cankers Disease (TCD) on Walnut. https://www. aphis.usda.gov/plant_health/plant_pest_info/tcd/downloads/ NationalResponseFramework.pdf 
U.S. Department of Commerce National Oceanic and Atmospheric Administration (2016) Main Hawaiian Islands Monk seal management plan. U.S. Department of Commerce National Oceanic Atmospheric Administration, National Marine Fisheries Service, Pacific Islands Regional Office, Honolulu, $72 \mathrm{p}$

U.S. Marine Corps (2001) Marine Corps Base Hawaii, supporting readiness and global projection. http://www.mcbhawaii. marines.mil/News/News-Article-Display/Article/538881/ aavs-improve-bird-habitat/

University of Guam and the Secretariat of the Pacific Community (2014) Regional biosecurity plan for Micronesia and Hawaii. http:// guaminsects.net/anr/sites/default/files/RBPC.pdf

Utley C, Nguyen T, Roubtsova T et al (2013) Susceptibility of walnut and hickory species to Geosmithia morbida. Plant Dis 97:601-607

Valtonen A, Jantunen J, Saarinen K (2006) Flora and lepidoptera fauna adversely affected by invasive Lupinus polyphyllus along road verges. Biol Conserv 133:389-396

van Riper C, van Riper SG, Goff ML, Laird M (1986) The epizootiology and ecological significance of malaria in Hawaiian land birds. Ecol Monogr 56:327-344

Vanderploeg HA, Liebig JR, Carmichael WW et al (2001) Zebra mussel (Dreissena polymorpha) selective filtration promoted toxic Microcystis blooms in Saginaw Bay (Lake Huron) and Lake Erie. Can J Fish Aquat Sci 58:1208-1221

Von der Lippe M, Kowarik I (2007) Long-distance dispersal of plants by vehicles as a driver of plant invasions. Conserv Biol 21:986-996

Voulgaridis V, Vassiliou VG (2005) The walnut wood and its utilization to high value products. Acta Hortic 705:69-81

Wang X (2012) Heat treatment of wood for invasive forest pests. In: Bradshaw BK, Ross RJ, Wang X, Wiemann MC (eds) Wood utilization options for urban trees infested by invasive species. University of Minnesota, Duluth

Watts DA, Moore GW (2011) Water-use dynamics of an invasive reed, Arundo donax, from leaf to stand. Wetlands 31:725-734

Weniger BG, Warren J, Forseth V et al (1984) Human bubonic plague transmitted by a domestic cat scratch. J Am Med Assoc 251:927-928

Whisenant SG (1989) Changing fire frequencies on Idaho's Snake River Plains: ecological and management implications. Symposium on Cheatgrass Invasion, Shrub Die-Off and Other Aspects of Shrub Biology and Management. Las Vegas, NV. April 5-7, pp 4-10

Whitehill JGA, Opiyo SO, Koch JL et al (2012) Interspecific comparison of constitutive ash phloem phenolic chemistry reveals compounds unique to Manchurian ash, a species resistant to emerald ash borer. J Chem Ecol 38:499-511

Williams SC, Ward JS (2010) Effects of Japanese Barbarry (Ranunculales: Beridacaeae) removal and resulting microclimate changes on Ixodes scapularius (Acari: Ixodidae) abundances in Connecticut, USA. Environ Entomol 39:1911-1921

Williams F, Eschen R, Harris A et al (2010) The economic cost of invasive non-native species of Great Britain. CABI, Surrey, pp 1-199

With KA (2002) The landscape ecology of invasive spread. Conserv Biol 16:1192-1203

Witmer GW, Sanders RB, Taft AC (2003) Feral swine - are they a disease threat to livestock in the United States? In: Fagerstone KA, Witmer GW (eds) Proceedings of the 10th wildlife damage management conference. USDA National Wildlife Research Center - Staff Publications, Hot Springs

Yap TA, Koo MS, Ambrose RF et al (2015) Averting a North American biodiversity crisis: a newly described pathogen poses a major threat to salamanders via trade. Science 349(6247):481-482

Young SL, Gopalakrishnan G, Keshwani DR (2011) Invasive plant species as potential bioenergy producers and carbon contributors. J Soil Water Conserv 66:45A-50A

Zavaleta E (2000) The economic value of controlling an invasive shrub. Ambio 29:462-467

Zedler JB, Kercher S (2010) Causes and consequences of invasive plants in wetlands: opportunities, opportunists, and outcomes. Crit Rev Plant Sci 23:431-452

Zink TA, Allen MF, Heindl-Tenhunen B, Allen EB (1995) The effect of a disturbance corridor on an ecological reserve. Restor Ecol 3:304-310

Ziska LH, Bunce JA, Goins EW (2004) Characterization of an urbanrural $\mathrm{CO} 2 /$ temperature gradient and associated changes in initial plant productivity during secondary succession. Oecologia 139:454-458

Open Access This chapter is licensed under the terms of the Creative Commons Attribution 4.0 International License (http://creativecommons. org/licenses/by/4.0/), which permits use, sharing, adaptation, distribution and reproduction in any medium or format, as long as you give appropriate credit to the original author(s) and the source, provide a link to the Creative Commons license and indicate if changes were made.

The images or other third party material in this chapter are included in the chapter's Creative Commons license, unless indicated otherwise in a credit line to the material. If material is not included in the chapter's Creative Commons license and your intended use is not permitted by statutory regulation or exceeds the permitted use, you will need to obtain permission directly from the copyright holder. 